\title{
I Introduction: Secrecy and Maimonideanism
}

\section{Esotericism, Disguise, and Camouflage in a Generation of Discontent: Leo Strauss, Mircea Eliade, and Gershom Scholem}

In the latter half of the 1930s, two grand and original scholarly narratives were formulated regarding the way in which philosophy and religion had previously been understood. The formulators of these narratives were European scholars who, not finding academic positions in their homelands, ended up becoming professors at the University of Chicago and leading intellectuals in the United States. The writings of the German-born Jewish professor of political philosophy Leo Strauss and the Romanian-born historian of religion Mircea Eliade revolutionised the way in which many scholars addressed major issues in the humanities, and their impact has been felt long after their deaths.

In a series of monographs, Strauss introduces the concept that there is a strong propensity toward esotericism in Western philosophy that is conditioned by the inherent tension found in society between the rulers and the multitude on the one hand and the searcher of truth-that is, the critical philosopher-on the other. The founding event for this longstanding propensity was the condemnation and execution of Socrates. This tendency was assumed to have informed not only some parts of classical Greek philosophy, but also important segments of medieval thought, specifically Muslim philosophy, falsafah, some parts of Jewish philosophy, especially that of Maimonides and his followers, and some aspects of premodern European philosophy. ${ }^{1}$

Strauss's proposal put on the agenda a new way of carefully reading philosophical texts, which were themselves written by many thinkers who were aware of soci-

\footnotetext{
1 There are many fine expositions of Strauss's sometimes evasive methodological approach. See, for example, Shlomo Pines's concise piece "On Leo Strauss," trans. Aryeh Motzkin, Independent Journal of Philosophy 5/6 (1988): 169-71; Rémi Brague, "Leo Strauss et Maimonide," in Maimonides and Philosophy, eds. Shlomo Pines and Yirmiyahu Yovel (Dordrecht: Kluwer Academic Publishers, 1986), 246-68; Thomas L. Pangle, Leo Strauss: An Introduction to His Thought and Intellectual Legacy (Baltimore: Johns Hopkins University Press, 2006); Kenneth Hart Green, Jew and Philosopher: The Return to Maimonides in the Jewish Thought of Leo Strauss (Albany, NY: SUNY Press, 1993); Arthur M. Melzer, Philosophy Between the Lines: The Lost History of Esoteric Writing (Chicago: Chicago University Press, 2014); Eugene R. Sheppard, Leo Strauss and the Politics of Exile: The Making of a Political Philosopher (Waltham, MA: Brandeis University Press, 2006); and David N. Myers, Resisting History: Historicism and Its Discontents in German-Jewish Thought (Princeton: Princeton University Press, 2003), 106-29. For expositions of Strauss's thought dealing with issues to be discussed below, see, more recently, Haim O. Rechnitzer, Prophecy and the Perfect Political Order: The Political Theology of Leo Strauss [Hebrew] (Jerusalem: Bialik Institute, 2012), and Carlos Fraenkel, Philosophical Religions from Plato to Spinoza: Reason, Religion, and Autonomy (New York: Cambridge University Press, 2012), 32-35, as well as Avihu Zakai and David Weinstein, Exile and Interpretation: The Shaping of Modern Intellectual History in the Age of Nazism and Barbarism [Hebrew] (Tel Aviv: Resling, 2014), 93-130.
} 
ety's tendency to persecute free thinkers. He was concerned not only with what had been written, but also with questions related to how it was written; namely, what had been omitted and what had been consciously suppressed. Strauss's thought contains a basic polarity between "Jerusalem" (religion or faith) and "Athens" (philosophy). This polarity was adopted and adapted by several thinkers active within the framework of the three monotheistic religions. ${ }^{2}$ The latter approach can be seen as "rationalist" and critical, the former as much more mythical and fideistic. In a way, Strauss proposed a "hermeneutics of suspicion"-to borrow a phrase from another contextwhile Eliade, at least in the earlier phases of his career, can be depicted as a thinker who resorts to a "hermeneutics of confidence."

Mircea Eliade articulates a contrary tendency to that of Strauss. He regards the mythical, archaic type of religion as the more authentic form of spiritual life, antithetical to the later monotheistic religions that he imagined to be grounded in a proclivity towards attributing importance to events in history rather than to cosmological myths. ${ }^{3}$ He proposes the historical evolution of religion to be an ecstatic-orgiastic attempt to overcome linear time by means of myths and rituals. Our current linear vision of time, in this view, is a negative development because it is essentially accompanied by a process of demythologisation, a characteristic of the Judaeo-Christian approach, which is strongly connected to an apotheosis of history. Also crucial for Eliade's scholarly approach, as well as for some of his literary works, is the assumption that the sacred is camouflaged within the profane (and sometimes the banal) and that its presence, traces, or secrets should be deciphered by means of hermeneutics that he rarely used and only delineated in general and vague terms. ${ }^{4}$

Theories of disguise are present in the thought of these two scholars in quite a significant yet opposing manner. They may be understood as representing two different mentalities, reflecting a famous opposition formulated by Karl Jaspers: Strauss represents the axial mentality and Eliade the preaxial mentality. Put in another way, while Strauss inhabited an intellectual universe and espoused a distant and implicit critique of the essence of the ordinary social and political order, Eliade personally believed, especially in his youth, in what I call a magical universe. This magical universe is a type of reality-replete with cosmic homologies, correspondences, se-

2 David Janssens, Between Athens and Jerusalem: Philosophy, Prophecy, and Politics in Leo Strauss's Early Thought (Albany, NY: SUNY Press, 2008); Steven B. Smith, ed., The Cambridge Companion to Leo Strauss (Cambridge: Cambridge University Press, 2009); Susan Orr, Jerusalem and Athens: Reason and Revelation in the Work of Leo Strauss (Lanham, MD: Rowman \& Littlefield Publishers, 1995); Fraenkel, Philosophical Religions, passim.

3 See Moshe Idel, Mircea Eliade: From Magic to Myth (New York: Peter Lang, 2014).

4 Moshe Idel, "The Camouflaged Sacred in Mircea Eliade’s Self-Perception, Literature, and Scholarship," in Hermeneutics, Politics, and the History of Religions: The Contested Legacies of Joachim Wach and Mircea Eliade, eds. Christian K. Wedemeyer and Wendy Doniger (New York: Oxford University Press, 2010), 159-95. Though there are some differences between Eliade's early thought and his later thought, which should not concern us here, this approach remained fundamental throughout. 
crets, and sympathies-that is the locus for extraordinary events and miracles that reflect an ontologically porous reality, not just ancient religious beliefs. ${ }^{5}$

For Strauss, Western philosophy-pre-eminently an elitist preoccupation-involves an esoteric dimension in many important cases. For Eliade, however, the true religion-namely, the archaic one-is essentially exoteric, although the "sacred" may be camouflaged and thus may be secretly present in nature and in historical events (i.e., the profane). Eliade specifies that it is within the "banal" that the sacred is eventually camouflaged. Both scholars were conservative thinkers, concerned with the preservation of the current situation rather than attempting to ignite or cope with change. In a way, the two scholars considered ancient events-the trial of Socrates in Athens for Strauss and the worldviews in archaic religions for Eliade-as both a formative and a higher form of experience when compared to what is called the JudaeoChristian tradition.

In each of these scholarly systems, we may speak about more universal types of human activities that transcend the more particularist specific types of prevailing religious orientations in the present; what Eliade calls "mental horizons." In a way, Eliade subscribes to a form of philosophia perennis, ${ }^{6}$ as does Strauss (at least insofar as Shlomo Pines describes him), but while the former searched for a pre-Socratic archaic ontology, the latter took as the starting point for his reflections Socrates's dialogical form and its political concerns as found in Plato. ${ }^{7}$ However, while Strauss is concerned with the status of the individual elite versus the wider community or society as part of a hidden confrontation, Eliade is concerned with what he would agree to call the populace; namely, with the persons participating in religious life within their society. In fact, he conceives the turning point in the history of religion to be the violent imposition of monotheistic faith on the Jewish population by what he calls "the Jewish elite."8

Unlike Strauss, who was exclusively concerned with decoding the hidden content of written documents composed solely by elite figures, Eliade was much more concerned with explaining the religious meanings of natural symbols and rituals that are characteristic of mostly pre-literate cultures-that is, with collective symbols and rites. He assumed, however, that archaic men understood some kind of secret wisdom by means of ritualistic practices which, though later obscured by historical

5 See Idel, Mircea Eliade, introduction. See also chapter 10 below.

6 See chapter 5 below. On Eliade and the esoteric movement in Western Europe, see Marcel Tolcea, Eliade Ezotericul, 2nd ed. (Bucharest: EST, 2012); Antoine Faivre, "Modern Western Esoteric Currents in the Works of Mircea Eliade: The Extent and the Limits of their Presence," in Wedemeyer and Doniger, Hermeneutics, 147-57; and Steven M. Wasserstrom, Religion after Religion: Gershom Scholem, Mircea Eliade, and Henry Corbin at Eranos (Princeton: Princeton University Press, 1999).

7 Pines, "On Leo Strauss."

8 See Moshe Idel, Ascensions on High in Jewish Mysticism: Pillars, Lines, Ladders (Budapest/New York: Central European University Press, 2005), 216-23. 
developments, are not entirely unretrievable today. In 1943, he remarked in his Portugal Journal:

The act of creation, ${ }^{9}$ the Eros, is capable of untying primordial powers and visions, of a strength that surpasses by far the contemporary mental horizon; cf. the mystique of the archaic orgies, Dionysus, etc. [...]. If there are certain archaic secrets that are accessible to man as such, to the raw man/animal, then those secrets reveal themselves only to the person who embodies the total Eros, the cosmic one, without problems, without neurasthenia. ${ }^{10}$

No doubt, as he testifies, neurasthenia was a malady that haunted Eliade in precisely this period of his life. At this time, he was serving as a cultural attaché at the Romanian embassy in Lisbon. While his wife, who was ill, travelled to Bucharest for a medical consultation, Eliade attempted to cure his own ailment by means of his participation in sexual orgies. ${ }^{11}$ He derived his approach to the existence of allegedly lost mental horizons from his early encounter (indeed, in his high school years) with Romanian folklore and what is now called Western esotericism. Later on, the impact of the latter became blurred in his writings. Studying in India towards the end of the 1920s, Eliade became acquainted with the theories and practice of yoga, which he understood, against its presupposed pre-Arian background, to be based on some forms of hidden correspondence between the human body and the cosmos.

While Eliade was a profoundly Dionysian type of thinker and writer, we may describe Strauss as an Apollonian type of thinker and writer: he was someone who turned to Greek history and classical philosophy in order to understand the dangers that philosophers may encounter. Eliade went much further back in time than Strauss in order to understand the archaic true religion that he believed could be retrieved from a variety of rituals, objects, and documents. While Eliade mainly focused his research on more popular and folkloric material, Strauss, on the other hand, was concerned with decoding hints found in elite speculative literatures. Or, to propose

9 In this context, this means procreation.

10 Mircea Eliade, Jurnalul Portughez şi alte scrieri, trans. Mihai Zamfir, ed. Sorin Alexandrescu (Bucharest: Humanitas, 2006), 1:200-201. On "secrets of the universe" in Eliade, see also Idel, Mircea Eliade, 7, 11, 36. Elsewhere, he speaks about the secrets of becoming divine, see Idel, 13; for discussions of his "secret life," see 34. Perhaps one should compare Eliade's claim of lost mental horizons whose secrets can be revealed by means of sexual orgies to the recurrent concept of the "horizon of mysteries"; namely, the spiritual realm of man found in several pieces by his somewhat older friend, Lucian Blaga, initially printed around 1937 in Ştiinţă şi creaţie vol. 1, Trilogia valorilor (Bucharest: Humanitas, 1996), 200-216; Artă şi valoare, vol. 3, Trilogia valorilor (Bucharest: Humanitas, 1996), 31-32, 154; and Diferenţialele divine. Aspecte antropologice. Fïnţa istorică (Bucharest: Humanitas, 1997), 143, 147.

11 On the relationship between orgies and neurasthenia in Eliade's life in this period, see Jurnalul Portughez, 1:118, 126, 199, 235. The comparison in the last passage between death, orgies, and war as a dramatic return to primordial unity shows the importance of violence in religious experiences. See also his view of orgies in The Myth of the Eternal Return, or, Cosmos and History, trans. Willard R. Trask (New York: Harper Torchbooks, 1959), 57-58. 
another typology: while Strauss was informed by Platonic political esotericism related to the structure of society, which has nothing to do with a specific cosmology, Eliade was more concerned with mysteriology as developed before Plato's time in Pythagoreanism and Orphism. Indeed, in his youth, Eliade was very interested in Greek mystery religions: he would later claim that he reconstructed a Pre-Socratic ontology in his work.

These differences notwithstanding, both Strauss and Eliade were not merely influential scholars in academia: they were mystagogues who aspired to initiate their followers into a sort of art which they considered to be a forgotten or neglected lore, relevant not only for historians of philosophy or religion, but also for the people living in the present. Thus, two entirely different mystical approaches to thought (one philosophical-esoteric and the other mythical-exoteric) coexisted at the University of Chicago in the very same years, although I assume that they did not intersect with or react to each other either technically or conceptually. I am not acquainted with any significant dialogue, either oral or written, between these two thinkers. The aims of these two eminent scholars-similar to that of Gershom Scholem-were to be part of minorities who promoted what they claimed to be forgotten mental universes. The return of the repressed, though taking such different forms, also represents a turn from the Enlightenment faith in future utopias to proposals to learn much more from the forgotten past.

The two thinkers were part of what I call the "generation of discontents," which also includes other major figures such as Gershom G. Scholem. German-born like Strauss, Scholem had good relations with both him and Eliade. His academic approach, which revolutionised the study of Kabbalah, held a different view of religion than Strauss and was closer to Eliade's opinion. Scholem believed that the real vital power in Jewish religion was not Jewish philosophy, but a mythical revival of themes that generated the emergence of Kabbalah in the Middle Ages. Kabbalah is a prominently esoteric type of religious lore that was, according to Scholem, profoundly permeated by Gnosticism and, to a substantial extent, Neo-Platonism. Though in spirit he had a very critical method that was a lot closer to Strauss's textual approach, Scholem's attitude was much more historically oriented. His vision of the content of his subject matter (Kabbalistic literature) was much closer to Eliade's, as he emphasised the esoteric, symbolic, and mythical dimensions of the study of Kabbalah. ${ }^{12}$

More importantly, Scholem also advanced a theory that attributes a transcendental status to the divine realm-the sefirot or the ten divine powers, which is paramount in the Kabbalistic theosophical structure-that can be expressed or intuited only by means of what he called symbols, mainly biblical words, whose hidden sig-

12 For a comparison between Strauss and Scholem, see Sheppard, Leo Strauss, 114-16. For a recent comparison between Eliade's and Scholem's approaches to mysticism, see Philip Wexler, Mystical Sociology: Toward Cosmic Social Theory (New York: Peter Lang, 2013), 73-108. See also the next footnote. 
nificance Kabbalists knew how to decipher. ${ }^{13}$ For Scholem, the symbolic mode was understood as pointing to the transcendental, ultimate reality: it was considered to be the main sort of discourse in Kabbalah, representing a special form of esotericism, one that involves a kind of ineffability. In some cases, this essential type of esotericism is more connected to the feeling that there are supernal mysteries that are understood to be related to a reality that is difficult to understand or intuit. Political esotericism, by contrast, deals with issues that can be explained to any intelligent person. At least once, Scholem resorts to the word "camouflage," 14 and one of his Israeli editors even claimed that he was holding on to a sort of Zionist esoterica. ${ }^{15}$

In a way, this assumption may be connected to a vision expressed in some of his documents regarding the existence of a metaphysical core of reality for which the Kabbalists were searching; a scholar may also touch this core by decoding symbols, or may at least wait for a hint coming from this same core of reality, which he called "the mountain." ${ }^{16}$ As with Eliade, Scholem assumes the existence of an objective ontology of the sacred both in the Kabbalistic sources he studied and (at least implicitly) in the work of the scholar who aspires to contact that sacred dimension of reality. Hidden in texts, in nature, or in reality, the secret (or mysterious) dimension haunted modern scholars much more than it did their nineteenth-century predecessors.

The three authors reflect, overtly and implicitly, uneasiness with their respective religious establishments; they attempt to unearth different, sometimes even clandestine, narratives lying in the bosom of the sources of Western culture which were, according to their opinion, forgotten or sometimes even intentionally suppressed. Though working on different materials and drawing different conclusions, all three scholars attempted to reconstruct lost and forlorn narratives that (at least implicitly) had a bearing on the modern world.

Moreover, all three were emigrants whose decisions and political circumstances took them far away from their initial intellectual backgrounds, which nevertheless continued to inform their approaches. Ultimately, they became intellectual heroes in their respective countries of origin. ${ }^{17}$ In the following, we shall be concerned with several issues that were treated in the studies by Strauss and Scholem, different

13 See Moshe Idel, Old Worlds, New Mirrors: On Jewish Mysticism and Twentieth-Century Thought (Philadelphia: University of Pennsylvania Press, 2010), 83-131.

14 See Wasserstrom, Religion after Religion, 59.

15 As I heard from Professor Avraham Shapira, the editor of several collections of his articles in Hebrew.

16 See Moshe Idel, Kabbalah: New Perspectives (New Haven: Yale University Press, 1990), 12.

17 Sheppard, Leo Strauss. For the claim that Scholem felt like an exile while living in Israel, see Irving Wohlfarth, “'Haarscharf an der Grenze zwischen Religion und Nihilismus.' Zum Motiv des Zimzum bei Gershom Scholem,” in Gershom Scholem: Zwischen den Disciplinen, eds. Peter Schäfer and Gary Smith (Frankfurt am Main: Suhrkamp, 1995): 176-256. Eliade had been in exile from Romania since late 1944; he was active in Romanian exile circles in Paris and Chicago and contributed to Romanian journals printed by exiles. 
as their intellectual concerns were. In this context, another famous émigré should be mentioned: Hans Jonas, who, influenced by Martin Heidegger's existential philosophy, offered a sharp existential understanding of Gnosticism. Jonas's views on Gnosticism deeply influenced the way Scholem understood Kabbalah as predominantly Gnostic and mythical. Following Jonas, in the late thirties, Scholem came to understand Kabbalah as an antagonistic mystical phenomenon that was at least antithetical to the allegedly anti-mythical Rabbinic legalism. ${ }^{18}$

It should be emphasised that these concerns with the revivals of repressed wisdom were flowering in a period when the Freudian approach had become more and more widespread. This approach included the prevailing assumption that the unconscious is a determining power in individual and social life, the need to decipher its symbolic expressions in dreams and otherwise, and the use of Greek myth in order to make sense of what Freud called complexes. The title of one of Freud's most influential books, Civilization and Its Discontents, published in 1930, wonderfully captures his general approach, as well as what I see as the basic situation that characterised the elite European scene. This discontent is especially true insofar as several elite Jewish figures were concerned; a reason that is obvious in the interest in and spread of melancholia, another topic addressed earlier by the founder of psychoanalysis. ${ }^{19}$

In this context, the prominent role Carl G. Jung has played in the discourse on religion since the 1930s should be mentioned. He attempted to retrieve what he considered to be the forgotten archetypes that informed not only the classical religions, but also a variety of other types of literatures, such as alchemy, not to mention Eastern esoteric literatures. ${ }^{20}$ Through the Eranos conferences in Ascona, he was in contact with both Eliade and Scholem for many years. These conferences were part of a sort of religious movement that-discontented with the religious landscape of its generation-attempted to explore alternative religious avenues through using critical tools. Moreover, although it had some earlier sources, it was also in the 1930s that the esoteric movement found its most important advocate, René Guénon, an influential figure in some circles in Europe and elsewhere, who was discontented with the academic approach to religious studies due to the problems he had had getting his $\mathrm{PhD}$ thesis accepted by the famous scholar Sylvain Lévi.

In a way, the turn to esotericism constitutes a somewhat Romantic reaction to the Enlightenment's unbalanced worship of rationalism, which nevertheless was carried out by rational scholars who turned their gaze to literatures that had previously been misunderstood or neglected. Thus, a return to the past in order to retrieve meaningful

18 Jonas's view of Gnosticism, which influenced Scholem's and Isaiah Tishby's Gnostic understanding of Kabbalah, needs a separate study. See Idel, Old Worlds, New Mirrors, 133-45.

19 Moshe Idel, Saturn's Jews: On the Witches' Sabbat and Sabbateanism (London/New York: Continuum, 2011), 91-97.

20 See Moshe Idel, "Androgynes: Reflections on the Study of Religion," in Labirinti della mente: Visioni del mondo. Il lascito intellettuale di Elémire Zolla nel XXI secolo, ed. Grazia Marchianò (Torrita di Siena: Società Bibliografica Toscana, 2012): 17-48. 
experiences and situations, according to the new scholarly interpretation, was a prevalent mode of approach in 1930s Europe, and more examples in this direction can be adduced in this context.

Last but certainly not least among those I consider “discontents” are Franz Kafka and his great admirer Walter Benjamin: both had a deep impact on Scholem, although Kafka, despite belonging to the group of discontents, was much more concerned with the enigmatic universe as it is seen now than with a secret layer of texts that can be only understood in principle but never wholly known in the present. Benjamin was probably also influenced by the theory of language devised by Abraham Abulafia, who will be the subject of our discussion below, by means of Scholem himself, who, when in the earliest phases of contact with Benjamin in Munich, wrote an unfinished doctoral thesis on Kabbalistic theories of language, especially that of Abulafia. Scholem did not finish this thesis because he found the topic to be very difficult and he later shifted his focus of study to the Book Bahir. ${ }^{21}$

I propose to study these scholarly approaches both seriously and critically, since each opened new vistas of thought while being conditioned by specific types of literatures and historical situations. ${ }^{22}$ However, a precondition for the utilisation of these approaches and any others that have been formulated independently of the analysed material is a good acquaintance with all the available pertinent primary source materials, their many interpretations by other scholars, and their multiple backgrounds and contexts. These materials should be tackled with concern for all of their complexities, inconsistencies, and fluidity. Interpreters of these materials even ought to allow for the possibility of contradictions and, as much as possible, to avoid reductionist interpretations that are more likely to prove the pertinence of the interpreter's adopted methods and overarching monochromatic schemes than to display a deeper understanding of the contents of the interpreted texts, as we will see below. An example of such reductionism is the adoption of Strauss, Eliade, Scholem, or any other modern method's "solid grids" of interpretations without further reflection as to their strengths in terms of the problems at hand.

The concern with esotericism has been significantly enhanced in recent decades with the emergence of a new trend in research dealing with what has been labelled "Western esotericism," a variety of literature written in more recent centuries, initiated by Antoine Faivre ${ }^{23}$ and continued by Wouter J. Hanegraaff. ${ }^{24}$ The various

21 See Idel, Old Worlds, 168-75.

22 See Idel, Ascensions on High, 4-10.

23 See especially Antoine Faivre, Access to Western Esotericism (Albany, NY: SUNY Press, 1994).

24 Wouter J. Hanegraaff, Esotericism and the Academy: Rejected Knowledge in Western Culture (Cambridge: Cambridge University Press, 2012), and the book he co-authored with Antoine Faivre, Western Esotericism and the Science of Religion (Leuven: Peeters, 1998). For a survey of this development and additional studies, see Alessandro Grossato, ed., Forme e correnti dell'esoterismo occidentale (Milan: Medusa, 2008). See also Antoine Faivre, Roelof van den Broek, Jean-Pierre Brach, and Wouter Hanegraaff, eds., Dictionary of Gnosis and Western Esotericism (Leiden: Brill, 2005). 
forms of Western esotericism were influenced in different forms and in varying intensities by Jewish Kabbalah, or, more specifically, by the mediation of Christian Kabbalah, which appropriated some facets of Kabbalistic symbolism and developed in small circles in the late eighteenth and nineteenth centuries, bypassing the "rationalism" of the Enlightenment. Although this trend has been defined in various ways by Faivre and Hanegraaff, I do not accept that their descriptions, which may be appropriate for later phenomena, apply to the method of the medieval Kabbalist, especially since these scholars assume a form of incarnationalism ${ }^{25}$ that is, in my opinion, clearly absent in the Kabbalistic texts I analyse below.

These categories, as used by scholars in the field, represent to a greater extent the reverberations of Henry Corbin's often ahistorical approach to mysticism that has been imposed on texts and basic mystical concepts from Islam and other religions as if they reflect some form of ontological experience. ${ }^{26}$ In a way, this is a reification of concepts that Corbin skilfully and repeatedly used in his influential writings, as if these concepts represent some sort of reality in the same vein that may be found in many of the writings of Eliade and Jung. In his writing, the Sufi concept of the "world of images" ('âlam al-mițāl), which Corbin translated as mundus imaginalis, turned into a form of objective ontology rather than the view of a specific Sufi school alone. Corbin's views sometimes hinged on the scholarly reading of mysticism beyond Islam, as well as on a form of psychoanalysis.

With the penetrating scholarship on Kabbalah established by Gershom Scholem and his students, the medieval esoteric phenomena came to the attention of general scholarship on the Middle Ages and Western esotericism. Though the literature belonging to what is called Western esotericism was written much later than Abulafia's period, belonging as it does to pre-modern times, it is conceptually much more complex and syncretistic than the texts we shall be dealing with below. The emergence of such an approach in recent scholarship constitutes, in my opinion, a move with which a scholar writing about esotericism would do well to be acquainted, even more so when some of its manifestations are reflected in the categories used by

25 Hanegraaff, Esotericism and the Academy, 350, 353-54.

26 Hanegraaff, 341-46. The combination of the categories of incarnation with both esotericism and the imaginal, characteristic of Corbin's mysteriology, had a deep impact on Elliot Wolfson's conceptualisation of Kabbalah, a fact that he sometimes indicates explicitly. See, for example, his "Textual Flesh, Incarnation, and the Imaginal Body: Abraham Abulafia’s Polemic with Christianity," in Studies in Medieval Jewish Intellectual and Social History: Festschrift in Honor of Robert Chazan, eds. David Engel, Lawrence H. Schiffman and Elliot R. Wolfson (Leiden: Brill, 2012): 189-226; his Language, Eros, Being: Kabbalistic Hermeneutics and Poetic Imagination (New York City: Fordham University Press, 2004), xii, xviii, 28-29, 239, 391, notes 3, 5, 392; note 10, 239; and his "Kenotic Overflow and Temporal Transcendence: Angelic Embodiment and the Alterity of Time in Abraham Abulafia,” Kabbalah 18 (2008): 144-45, notes 40, 44, 147; in note 53, he also applies Corbin's views to Abulafia. For methodological problems related to Corbin's rather idiosyncratic vision of religion, see Wasserstrom's Religion after Religion, 172-81. See also Appendix E below. 
scholars of Kabbalah in order to analyse the writings of the Kabbalist under discussion. ${ }^{27}$

By enumerating the above scholars and their approaches, my intention is to point out that there is nothing like one single general type of esotericism; this is also the case in Judaism. Modern speculations about common denominators between the various forms of esotericism are more often than not reductive generalisations. ${ }^{28}$ I would say that even in more specific literatures, such as Jewish philosophy or Kabbalah, there are different and even diverging esoteric approaches. This is my working hypothesis as to the existence of various types of Jewish thought in general and of Kabbalah in particular. Although those different forms of imaginaire sometimes converged or intersected, they should nevertheless first be understood in themselves. ${ }^{29}$ I do not intend to offer a comprehensive typology of esotericism here, but rather to address those types of secrecy that are related or antithetical to some views of secrecy found in the specific medieval texts I shall address below. By addressing this secrecy, I will be able to interrogate these texts in a new way.

One of the most seminal figures in Strauss's grand narrative was Maimonides, a pivotal thinker in the general history of Judaism, the legalistic as well as the theological. Strauss devoted much energy and many publications to Maimonides's esotericism. Maimonides was also the starting point of Strauss's articulation of his method in depicting the history of Western philosophy. ${ }^{30}$ The huge impact of Strauss's approach is obvious in a long series of studies of Maimonides produced by many recent scholars, ${ }^{31}$ though important forms of critiques of Strauss's approach have also been

27 See previous footnote.

28 This is also the case in Georg Simmel, "The Sociology of Secrecy and of Secret Societies," American Journal of Sociology 11 (1906): 441-98, which deals with organisations and secrecy, a topic that does not concern us below, interested though I nevertheless am in the necessity of distinguishing between roles played by two elites in the history of Kabbalah.

29 See especially the theory of models as formulated in Moshe Idel, Hasidism: Between Ecstasy and Magic (Albany, NY: SUNY Press, 1995), 45-145.

30 His most influential papers are "The Literary Character of the Guide of the Perplexed," in his Persecution and the Art of Writing (Chicago: University of Chicago Press, 1952): 38-94, and "How to Begin to Study the Guide of the Perplexed," printed as a preface to Shlomo Pines's translation of the Guide of the Perplexed (Chicago: Chicago University Press, 1963), 1:i, xi-lvi. See also Alfred L. Ivry, "Leo Strauss and Maimonides," in Leo Strauss' Thought, ed. Alan Udoff (Boulder: Reinner, 1991): 75-91, and Kenneth Hart Green, ed., Leo Strauss on Maimonides: The Complete Writings (Chicago: University of Chicago Press, 2013).

31 On Maimonides's esotericism, the importance of which for Abulafia will be the starting point of many of my discussions below, there is a long series of studies written after Strauss. I quote below only the most seminal ones: Aviezer Ravitzky, "Samuel ibn Tibbon and the Esoteric Character of the Guide of the Perplexed," AJS Review 6 (1981): 87-123; Ravitzky, "The Secrets of the Guide to the Perplexed: Between the Thirteenth and Twentieth Centuries," in Studies in Maimonides, ed. Isadore Twersky (Cambridge, MA: Harvard University Press, 1990), 159-207, reprinted in his History and Faith: Studies in Jewish Philosophy (Amsterdam: Gieben, 1996): 205-303; Ravitzky, "Maimonides: Esotericism and Educational Philosophy," in The Cambridge Companion to Maimonides, ed. Kenneth See- 
addressed. ${ }^{32}$ In my opinion, Maimonides was a reformist who was discontented with the prevailing understandings of Judaism among most Rabbinic Jews. Indeed, his

skin (Cambridge: Cambridge University Press, 2005): 300-323; Moshe Halbertal, Concealment and Revelation: Esotericism in Jewish Thought and Its Philosophical Implications, trans. Jackie Feldman (Princeton: Princeton University Press, 2007), 49-68; Howard Kreisel, "Esotericism to Exotericism: From Maimonides to Gersonides," in Study and Knowledge in Jewish Thought, ed. Howard Kreisel (Beer-Sheva: Ben-Gurion University Press, 2006): 1:165-84; Kreisel, "The Guide of the Perplexed and the Art of Concealment" [Hebrew], in By the Well: Studies in Jewish Philosophy and Halakhic Thought Presented to Gerald J. Blidstein, eds. Uri Ehrlich, Howard Kreisel, and Daniel J. Lasker (Beer-Sheva: Ben-Gurion University Press, 2008): 487-507; Dov Schwartz, Contradiction and Concealment in Medieval Jewish Thought [Hebrew] (Ramat-Gan: Bar-Ilan University Press, 2002), 68-111; Schwartz, "The Separate Intellects and Maimonides's Argumentation (An Inquiry into Guide of the Perplexed II, 2-12)," in Between Rashi and Maimonides: Themes in Medieval Jewish Thought, Literature and Exegesis, eds. Ephraim Kanarfogel and Moshe Sokolow (New York: Yeshivah University Press, 2010): 59-92; Yair Lorberbaum, “'The Men of Knowledge and the Sages Are Drawn, As It Were, toward This Purpose by the Divine Will' (The Guide of the Perplexed, Introduction): On Maimonides's Conception of Parables" [Hebrew], Tarbiz 71 (2001-2): 87-132; Lorberbaum, "On Contradictions, Rationality, Dialectics and Esotericism in Maimonides's Guide of the Perplexed," The Review of Metaphysics 55, no. 4 (2002): 711-50; Warren Zev Harvey, "The Mishneh Torah as a Key to the Secrets of the Guide," in Me'ah She'arim: Studies in Medieval Jewish Spiritual Life in Memory of Isadore Twersky, eds. Ezra Fleisher, Gerald Blidstein, Carmi Horowitz, and Bernard Septimus (Jerusalem: Magnes Press, 2001), 11-28; Harvey, "A Third Approach to Maimonides's Cosmogony-Prophetology Puzzle," HTR 74, no. 3 (1981): 287-301; Sara Klein-Braslavy, King Solomon and Philosophical Esotericism in the Thought of Maimonides [Hebrew] (Jerusalem: Magnes Press, 1996); Elliot R. Wolfson, Abraham Abulafia-Kabbalist and Prophet: Hermeneutics, Theosophy, and Theurgy (Los Angeles: Cherub Press, 2000), 38-52, especially 39, note 94; Menachem Kellner, Maimonides' Confrontation with Mysticism (Oxford: Littman Library of Jewish Civilization, 2006), 15-17; James A. Diamond, Maimonides and the Hermeneutics of Concealment: Deciphering Scripture and Midrash in the Guide of the Perplexed (Albany, NY: SUNY Press, 2002).

32 The earliest and more direct critiques of Strauss's theory from a scholar of Jewish thought are found in Julius Guttmann's posthumously printed On the Philosophy of Religion [Hebrew] (Jerusalem: Magnes Press, 1958); Herbert A. Davidson, Moses Maimonides, The Man and His Works (Oxford: Oxford University Press, 2004), 387-402; Davidson, "Maimonides on Metaphysical Knowledge," in Maimonidean Studies 3 (1995): 49-103; Eliezer Schweid, "Religion and Philosophy: The Scholarly-Theological Debate between Julius Guttmann and Leo Strauss," in Maimonidean Studies 1 (1990): 16395; Aviezer Ravitzky, Maimonidean Essays [Hebrew] (Jerusalem/Tel Aviv: Schocken, 2006), 59-80; Warren Zev Harvey, "Les Noeuds du Guide des Égarés: Une critique de la lecture politique de Leo Strauss," in Lumières médiévales, ed. Géraldine Roux (Paris: Van Dieren, 2009): 163-76; Harvey, "How Strauss Paralyzed the Study of the Guide of the Perplexed in the 20th Century" [Hebrew], Iyyun 50 (2001): 387-96; Menachem Kellner, Science in the Bet Midrash: Studies in Maimonides (Brighton, MA: Academic Studies Press, 2009), 33-44; Joseph A. Buijs, "The Philosophical Character of Maimonides's Guide-A Critique of Strauss' Interpretation,” Judaism 27 (1978): 448-57; and Halbertal, Concealment and Revelation, 149, 163. See also, more recently, Micah Goodman, The Secrets of The Guide to the Perplexed [Hebrew] (Or Yehudah: Devir, 2010). Mitigating as those scholars' critiques of Strauss position are for his famous thesis, Maimonides's esotericism is, however, not denied but qualified in a variety of ways. However, in other cases, like the studies of David Hartman and Isadore Twersky, Maimonides's thought was conceived in a more harmonious manner, emphasising the importance of the Great Eagle's Halakhic creativity and commitment for also understanding his philosophy. To 
most important book for the history of Jewish thought was emblematically entitled The Guide of the Perplexed, which refers to members of the Jewish faith whom he imagined were perplexed; the intention, then, was to guide these individuals through their alleged perplexities. His "guidance" in this book differs from the more traditional attitudes in his Halakhic works, especially insofar as the question of universalism is concerned, given that it mainly emerges from Neo-Aristotelianism. ${ }^{33}$

I will discuss the affinities between Maimonides's thought and that of Abulafia who preoccupies me throughout this book, a medieval figure who was deeply influenced by Maimonides's thought (including his esotericism, which scholars call "rationalism" in too general a manner). ${ }^{34}$ This figure, already also the subject of several studies by Gershom Scholem, is the Kabbalist Abraham ben Samuel Abulafia (1240c. 1291), ${ }^{35}$ and I will survey the evolution of his thought below. However, I am essentially concerned here with Abulafia's understanding of Maimonides, not with the latter's view per se. Unlike the Great Eagle, Abulafia was not a Halakhic figure, a decisive factor in his worldview that helps in understanding his extreme interpretations of Maimonides's philosophical thought and of Rabbinic Judaism.

Abulafia's thought never remained part of one specific conceptual genre; rather, it brings together some trends that were already to be found in the Jewish thought of both his own generation and that which preceded him. Too mystical for Strauss's cerebral approach, too philosophical and non-symbolic for Scholem's tendency to see Kabbalah as a pre-eminently symbolic, theosophical, and Gnostic-like lore, and practically unknown by Eliade, Abulafia's special approach should nevertheless be ana-

a certain extent, this is, in principle, also the approach of Aviezer Ravitzky. See note 70 below. Shlomo Pines, whose approach to Strauss's emphasis on esotericism was quite positive, moved in his later studies towards a position that differs from Strauss; he conceives the Great Eagle's thought as more sceptical, and this is also the case especially in Joseph Stern, The Matter and Form of Maimonides's Guide (Cambridge, MA: Harvard University Press, 2013). For a recent survey of scholarship on Maimonides and esotericism, see Omer Michaelis, “'It is Time to Act for the Lord: [They] Violate[d] Your Torah': Crisis Discourse and the Dynamics of Tradition in Medieval Judaism” (PhD diss., Tel Aviv University, 2018), especially 286, notes 806, 807.

33 For the intention of the guidance in the Guide, see Stern, The Matter and Form of Maimonides's Guide, 7.

34 In the following discussions, I try to avoid this term, since even in scholarship, it is used with an implicitly judgmental attitude. My approach assumes the existence of different forms of imaginaires that should not be judged by a critical scholar concerned with understanding the past.

35 On this Kabbalist, whose views will be the focus of our discussions here, see the more general, though influential, expositions of Gershom Scholem, especially in his Major Trends in Jewish Mysticism (New York: Schocken, 1960), 119-55, and his last series of lectures at the Hebrew University printed as The Kabbalah of Sefer ha-Temunah and of Abraham Abulafia [Hebrew], ed. Y. ben Schlomo (Jerusalem: Academon, 1969). 
lysed by taking into consideration aspects of these diverging approaches to mystical thought, also including that of Carl Jung, for example. ${ }^{36}$

In recent years, the writings of this Kabbalist have received special attention in scholarly studies; many of them have been printed for the first time, mainly by Amnon Gross, and several have been translated into English and some into French. However, very few pages of his voluminous output have been critically edited, and none of his books, with the recent exception of Sefer ha-Ot, ${ }^{37}$ has been subjected to a separate and detailed analysis in print. Most of the scholarship is grounded in a reading of only part of his identifiable writings, and even then the analyses were based on quotations taken from different books, sometimes outside of their immediate contexts, without exhausting the corpus of those writings. This situation has provoked significant misunderstandings and misrepresentations of Abulafia's thought, as we shall see below, especially in chapters 9 and 21. Moreover, the general intellectual context of his thought has only been partially addressed in scholarship; this context will be one of the main subjects of many of our discussions below, especially in part II of this study.

In the present study, I am particularly concerned with Abulafia's views on esotericism. ${ }^{38}$ A complex figure, Abulafia was also a devoted student of the Great Eagle's book at the same time as being a Kabbalist, and a self-proclaimed prophet and Messiah. These two last self-perceptions, which he expressed in both written and, we may assume, oral forms, were of course likely to elicit persecutions from various forms of the Jewish establishment, as indeed occurred. In this study, my claim will be that a seminal dimension of Abulafia's writings consists in the hiding of what he thought "true" religion is or ought to be, a view he adopted-or, perhaps, adapted-from Maimonides and several Muslim philosophical sources. This esoteric propensity was en

36 See Moshe Idel, The Mystical Experience in Abraham Abulafia, trans. J. Chipman (Albany, NY: SUNY Press, 1987), 109-11. See, in more general terms, Idel, Kabbalah: New Perspectives, 35, and Idel, Ascensions on High, 5, 9-10.

37 Abraham Abulafia, Księga Znaku: Rabbi Abraham Abulafia, רבי אברהם אבולעפיה, ספר האות, ed. Arje Krawczyk (Warsaw: Żydowski Instytut Historyczny, 2018).

38 See my monographs The Mystical Experience; Language, Torah, and Hermeneutics in Abraham Abulafia, trans. M. Kallus (Albany, NY: SUNY Press, 1989); Studies in Ecstatic Kabbalah (Albany, NY: SUNY Press, 1989); see also Rabbi Nathan ben Sa'adyah H̦ar'ar, Le Porte della Giustizia (Sha'arei Tzedeq), trans. Maurizio Mottolese, ed. Moshe Idel (Milan: Adelphi, 2001); Wolfson, Abraham Abulafia; Harvey J. Hames, Like Angels on Jacob’s Ladder: Abraham Abulafia, the Franciscans, and Joachimism (Albany, NY: SUNY Press, 2007); Robert J. Sagerman, The Serpent Kills or the Serpent Gives Life: The Kabbalist Abraham Abulafia's Response to Christianity (Leiden: Brill, 2011); and Shimeon Levy, "Sefer Ḥayyei ha-Nefeš” (MA thesis, Hebrew University, 1955). Sustained discussions on some topics in Abulafia's Kabbalah are also available in chapters of many of my other books, in particular Messianic Mystics (New Haven, CT: Yale University Press, 1998), 58-100, 295-302; Kabbalah in Italy, 12801510: A Survey (New Haven, CT: Yale University Press, 2010), 30-88, 297-98; Ben: Sonship and Jewish Mysticism (London/New York: Continuum, 2007), 276-376; Middot: Divine Attributes from Late Antiquity to Early Kabbalah, chapter 9 (in preparation); as well as in many studies by me and others to be referenced in chapter 1 footnotes 40 and 41. 
vogue among some of Maimonides's followers who were contemporaries of Abulafia. Nevertheless, Abulafia is the representative of this approach and one of the most radical of Maimonides's followers. More than any of the Maimonideans, he speaks about secrets, secrets of the Torah and secrets of existence, and this stark emphasis on secrecy should be taken into serious consideration when assessing his thought. I doubt whether a significant understanding of Abulafia's thought can ignore this dimension of his writings.

In these writings, political esotericism is coupled with an entirely different type of esotericism: eschatological esotericism, which is negligible in the writings of the Great Eagle. This type of esotericism refers to secrets dealing with a special understanding of the nature of redemption, the time of redemption, and the identity of the redeemer. Abulafia interpreted these traditional issues as also referring to personal and intellectual events, an approach that was prone to disrupt the prevailing approaches to these issues in traditional Judaism, which was more concerned with topics such as the signs and time of the Messiah or with the restoration of the ancient political and religious order for the sake of the entire nation. It seems that this messianic pretension was one of the main reasons for Abulafia's persecutions, along with the ban issued against him by the most prominent legalistic figure of that generation in Catalonia, the Kabbalist Rabbi Solomon ben Abraham ibn Adret. Less prominent in Abulafia's writings is the third type of esotericism: the essential one, which is conditioned by the relatively ineffable nature of the object of discussion or experience. In Abulafia's case, what he considers to be the true divine name is, although hidden in a variety of other names, not ineffable. ${ }^{39}$

Different as the two first types of esotericism are both conceptually and from the point of view of the sources that nourish them, political and eschatological esotericism are deeply related to each other in Abulafia's writings. For Abulafia, individual redemption constitutes the peak of natural religion, whose tenets are hidden as part of political esotericism, while the messianic redemption is part of eschatologicaland more popular-esotericism. Nevertheless, it is also possible to include personal redemption as part of eschatological esotericism. The contents of eschatological esotericism and its special methods of expression are related to gematria and combinations of letters also used for referring to secrets belonging to Abulafia's political esotericism. However, the uncommon manner of its expressions in the philosophical camp has deterred scholars of Maimonidean thought from dealing seriously with Abulafia's thought and has also prevented them from seeing him as an original part of the Maimonidean camp.

An effort to read some of Abulafia's discussions in the manner that Strauss recommended can contribute to a better understanding of the esoteric facet of this Kab-

39 See Oșar 'Eden Ganuz, ed. Gross (Jerusalem: 2000), 3:9, 354-55. See also the very important discussion in his early Mafteah ha-Ra'ayon, ed. Gross (Jerusalem: 2002), 69-70, where it is obvious that theological issues can be understood, but that they should nevertheless be hidden. 
balist's writings, as well as that of his oeuvre in general. These forms of esotericism differ dramatically from the kind of esotericism found in the vast majority of the writings belonging to the nascent Kabbalah in the twelfth century, a fact that distinguishes both the content and the rhetoric of Abulafia's secrets quite neatly from those of the early Kabbalists. ${ }^{40}$ The latter dealt with either the secrets of the divine realm and the relation of the commandments to the supernal powers or the source of the soul within the divine world and its vicissitudes in this and the other world; both of these nomian approaches were made in connection to the commandments. ${ }^{41}$

Needless to say, in my opinion, neither these secrets nor those of Abulafia constitute the surfacing of the contents of the ancient Jewish secrets mentioned in Rabbinic sources or their faithful continuation with a few changes. Nevertheless, I would

40 Closer to Abulafia in the modes of expression and numerical methods, but not in their philosophical content, are some of the writings of the Castilian ha-Kohen brothers, one of whom also influenced Abulafia. See Idel, "Sefer Yetzirah and Its Commentaries in the Writings of Rabbi Abraham Abulafia," Tarbiz 79 (2011): 519-27. On this circle of Kabbalists, see Daniel Abrams, “"The Book of Illumination' of Rabbi Jacob ben Jacob HaKohen: A Synoptic Edition from Various Manuscripts” [Hebrew] (PhD diss., New York University, 1993).

41 See my studies of early forms of Kabbalistic esotericism from the point of view of both rhetoric and content: "The Kabbalistic Interpretations of the Secret of Incest in Early Kabbalah" [Hebrew], Kabbalah 12 (2004): 89-199; “Sitre 'Arayot in Maimonides' Thought," in Maimonides and Philosophy, 84-86; "Commentaries on the Secret of 'Ibbur in 13th-Century Kabbalah and Their Significance for the Understanding of the Kabbalah at Its Inception and Its Development" [Hebrew], Da'at 72 (2012): 5-49; 73 (2012): 5-44; "The Secret of Impregnation as Metempsychosis in Kabbalah," in Verwandlungen: Archaeologie der literarischen Kommunikation 9, eds. Aleida Assmann and Jan Assmann (Munich: Fink, 2006): 349-68; and "The Jubilee in Jewish Mysticism," in Millenarismi nella cultura contemporanea, ed. Enrico I. Rambaldi (Milan: F. Angeli, 2000): 209-32. For the original Hebrew texts, some still in manuscript, which were translated and analysed in the last study, see the Hebrew version of this article printed in Joseph Kaplan, ed., Šilhei Me'ot-Qișam šel 'Idanim (Jerusalem: Shazar Center, 2005): 67-98, and "Secrets of the Torah in Abraham Abulafia." My claim in some of these studies is that there is quite a neat difference between the esotericism of the Nahmanidean Kabbalistic school on the one hand and what can be found among the followers of Rabbi Isaac the Blind on this topic on the other. To this effect, see my "We Have No Kabbalistic Tradition on This," in Rabbi Moses Nahmanides (Ramban): Explorations in His Religious and Literary Virtuosity, ed. Isadore Twersky (Cambridge, MA: Harvard University Press, 1983): 51-73. On esotericism and exotericism in Kabbalah in more general terms, see my Kabbalah: New Perspectives, 253-56. For other studies of Jewish esotericism in the thirteenth century, see Harvey J. Hames, "Exotericism and Esotericism in Thirteenth Century Kabbalah," Esoterica 6 (2004): 102-12; Daniel Abrams, "The Literary Emergence of Esotericism in German Pietism," Shofar 12, no. 2 (1994): 67-85, and its Hebrew version, "Esoteric Writing in Ashkenaz and Its Transition to Spain" [Hebrew], Mahanayyim: A Quarterly for Studies in Jewish Thought and Culture 6 (1993): 94-103, along with the next footnote. For secrecy in Abulafia's lifetime, see Hartley Lachter, “The Politics of Secrets: Thirteenth-Century Kabbalah in Context," JQR 101 (2011): 502-10; Lachter, "Jews as Masters of Secrets in Late Thirteenth-Century Castile," in The Jew in Medieval Iberia: 1100-1500, ed. Jonathan Ray (Boston: Academic Studies Press, 2012): 286-308, as well as Lachter, Kabbalistic Revolution: Reimagining Judaism in Medieval Spain (New Brunswick, NJ: Rutgers University Press, 2014), especially 8-26, 28-35, 37-43. 
say that such a continuation is found, mutatis mutandis, in the theory of the identification of the Torah and divinity as anthropomorphic structures conceived as a secret $(r a z)$ in the Hekhalot literature ${ }^{42}$ this continuation may also be found in the assumption that the divine names are part of an esoteric tradition. ${ }^{43}$ If there are additional ancient esoteric themes in the Jewish Middle Ages, they are probably the vestiges of Pythagorean theories, mediated mainly by the writings of Rabbi Abraham ibn Ezra, as we shall see in chapter 7 below. In any case, I do not intend to summarise the findings in those topics, but will deal with quite different kinds of secrets, more in vein with those of Strauss.

First, I will survey what seem to me to be the essential points of Maimonides's special contribution, especially in his Guide of the Perplexed, to the new trend in medieval Jewish thought that he established. I will then turn to the movement that can be designated as Maimonideanism, within whose framework Abulafia's esotericism should be understood incomparably more than any other type of esotericism. As in the case of the Great Eagle's hidden positions in his Guide of the Perplexed, analyses of the esoteric topics in Abulafia's writings are often haphazard, and their results debatable. However, these two authors' explicit and numerous references to the existence of important secrets necessitate such an arduous and sometimes perilous exercise. Ignoring the claims of the existence of these secrets will certainly not advance our understanding of their thought.

In addition to being an ardent student of the text of the Guide, Abulafia claims to have received secrets as to Maimonides's intentions both orally ${ }^{44}$ and, in many other cases, as revelations from above. From this point of view, Abulafia's literary corpus represents an interesting case study of the impact of philosophical (and essentially political) esotericism flowering beyond the more limited range of the Maimonidean

42 See, for example, my "The Concept of the Torah in Hekhalot Literature and Its Metamorphoses in Kabbalah” [Hebrew], JSJT 1 (1981): 23-84. See also my “'In a Whisper': On Transmission of Shi'ur Qomah and Kabbalistic Secrets in Jewish Mysticism," Rivista di storia e letteratura religiosa 47, no. 3 (2011): 477-85, and "The Image of Man above the Sefirot: R. David ben Yehuda he-Hasid's Theosophy of Ten Supernal Sahsahot and its Reverberations,” Kabbalah 20 (2009): 181-212.

43 On ancient Jewish esotericism related to divine names, see Guy G. Stroumsa, Hidden Wisdom: Esoteric Tradition and the Roots of Christian Mysticism (Leiden: Brill, 1996), 109-31. See also Halbertal, Concealment and Revelation, 13-33; Yehuda Liebes, God's Story: Collected Essays on the Jewish Myth (Jerusalem: Carmel, 2008), 163-76; Liebes, "The Work of the Chariot and the Work of Creation as Mystical Teachings in Philo of Alexandria," trans. James Jacobson-Maisels, in Scriptural Exegesis: The Shapes of Culture and the Religious Imagination. Essays in Honour of Michael Fishbane, eds. Deborah A. Green and Laura S. Lieber (Oxford: Oxford University Press, 2009): 105-20; Vita D. Arbel, Beholders of Divine Secrets: Mysticism and Myth in the Hekhalot and Merkavah Literature (Albany, NY: SUNY Press, 2003). See also the important study by Mohammad Ali Amir-Moessi, The Divine Guide in Early Shi'ism: The Sources of Esotericism in Islam, trans. David Streight (Albany, NY: SUNY Press, 1994) for early medieval Islamic sources.

44 See, for example, Mafteah ha-Šemot, ed. Gross (Jerusalem: 2001), 156: כבר קבלנו על פה מהות הכוונה. See also Sefer Gan Na'ul, 5, as well as some discussions on the secrets of the Guide, in chapter 4 note 76. 
authors as envisioned in modern scholarship, to say nothing of Maimonides himself. Though a Kabbalist, Abulafia's opus nevertheless requires an analysis that utilises Leo Strauss's thesis about persecution and the art of writing, even when a complex and quite diversified corpus of writings is involved. After all, Abulafia too was persecuted for his ideas for many years-and later even banned-and he too attempted to spread the contents of Maimonides's Guide, as we shall see in part III below. To be sure, political esotericism is not the only type of esotericism to be found in his writings; for example, he also adopted the Pythagorean secret of the Tetraktys, the doctrine of the centrality of the number four, as we shall see in chapter 7 below. However, in my opinion, political esotericism is the most important kind found in Abulafia's work, and its existence and ramifications will be the centre of many of our discussions below. This kind of esotericism has to do with the secrets regarding the transcendental and intellectual nature of God, kept from the greatest part of the society or community immersed in the traditional visions of God as anthropomorphic and anthropopathic.

\section{Maimonides and Jewish Mysticism}

In the twelfth century, the province of Al-Andalus hosted a Neo-Aristotelian renaissance among some Muslim thinkers; this renaissance occurred among some Jewish thinkers in the same area somewhat later. ${ }^{45}$ The most important of the Jewish thinkers born in Al-Andalus by far was Moses ben Maimon, Maimonides. In Egypt, where he went in order to escape the Almohadi persecutions in his native Al-Andalus, Maimonides followed some developments in earlier Muslim falsafah, represented mainly by Al-Fārābī and Avicenna in Asia, who were active much earlier, and by the Andalusian Muslim thinkers, who elaborated in various ways on the avenues opened by the Arabic translations of (mainly) Aristotelian texts. This is a clear example of the decisive influence of the speculative dimensions of Greek culture on some elites in Islamic thought and then, by the mediation of the latter, on some Jewish thinkers. This influence is constituted by the massive translations of several corpora of speculative writings stemming from a millennium or more beforehand that flourished in new geographical areas and in new intellectual and political circumstances.

Unlike the much more Neo-Platonic background of Muslim and Jewish thought in Al-Andalus in the eleventh and twelfth centuries, the turn to Neo-Aristotelianism towards the second part of the twelfth century is quite conspicuous. Indeed, follow-

45 See Sarah Stroumsa, “Thinkers of 'This Peninsula': Towards an Integrative Approach to the Study of Philosophy in al-Andalus," in Beyond Religious Borders: Interaction and Intellectual Exchange in the Medieval Islamic World, eds. David M. Freidenreich and Miriam Goldstein (Philadelphia: University of Pennsylvania Press, 2012): 44-53; Stroumsa, “The Muslim Context in Medieval Jewish Philosophy,” in The Cambridge History of Jewish Philosophy: From Antiquity through the Seventeenth Century, eds. Steven Nadler and Tamar Rudavsky (Cambridge: Cambridge University Press, 2008): 39-59. 
ing this renaissance, a new era in the religious history of Jewish philosophy and mysticism began. This new era was ushered in by the composition of Maimonides's theological chef d'oeuvre, The Guide of the Perplexed, in 1191 and its translations from Arabic into Hebrew shortly afterwards.

Only rarely in the history of Judaism has the appearance of one book generated such a dramatic religious turn in such a brief period while simultaneously triggering sharp and prolonged debates that reverberate among Jewish thinkers even today. Maimonides's grand-scale adoption of a combination of Neo-Aristotelian metaphysics, physics, logic, and psychology and Platonic negative theology and esotericism informs much of the discussions in his book, which he presents as an interpretation of allegedly lost Rabbinic secrets (a claim that was somewhat less evident in his earlier writings); this assumption became widespread and in many cases dramatically changed the conceptual landscape of some elite forms of Judaism from the early thirteenth century.

One of the most puzzling questions related to the impact of this treatise is that although it claims to be a guide, it is more of a puzzle, as Warren Zev Harvey insightfully elaborated following Maimonides's own remark in his introduction to the Guide. ${ }^{46}$ This is the reason why the presentation of his views below is to a certain extent a tentative attempt to put together hints that were never systematically treated either by Maimonides himself or even by his many followers. This lack of systematisation has much to do with esotericism and the need to hide some views that could have been considered to be heterodox, as they differ from traditional forms of Judaism or the Jewish collective memory; some of his views had been sharply criticised, just as Neo-Aristotelianism elicited persecutions from Muslim and Christian scholars in the very same period.

A major shift in the understanding of many elements found in a variety of Rabbinic traditions that Maimonides introduced to Judaism is a much more naturalistic understanding of it; that is, the acceptance of an organised universe with constant laws, sometimes described as nature (the Hebrew medieval neologism teva', which stems from the Arabic țabī'ah), which can be observed and understood as reflecting divine wisdom. Maimonides brings to Judaism the form of a stable cosmos as understood in some forms of Greek philosophy. ${ }^{47}$ Earlier forms of Judaism were concerned with the role played by the divine will, which freely intervenes in creation and history; after Maimonides, divine wisdom became the primary concern among his main followers.

46 See Warren Zev Harvey, “The Return to Maimonideanism,” JJS 42 (1980): 263, note 1.

47 The role played by the new understanding of reality in medieval Judaism because of the new philosophical vision of an ordered cosmos deserves a separate inquiry. Below, we shall address one such case of adopting the philosophical approach towards an ordered universe. On nature as differing from choice and accidents in the Aristotelian tradition, see the footnotes by Simon van den Bergh, the translator of Averroes' Tahäfut al-Tahäfut (The Incoherence of Incoherence) (London: Oxford University Press, 1954), 1:272; 2:95, note to $145.4 ; 148$, note to $266.1 ; 149$, notes to 271.2 and 272.2. 
In the realm of anthropology, this view translates to elevating intellectual activity to a sublime role that it had not played earlier, thus giving the philosopher the function of an educator of the masses, at least in principle. In many cases, this role has been identified with that of the prophet. In the case of Maimonides's own oeuvre, his thirteen principles of faith represent one such educational effort.

The intellectual dimension of reality, a new common denominator that is understood to be found in God, nature, and man, allowed for a new dynamic between these three factors. In order to generate such a picture, philosophers in the three religions had to de-anthropomorphise God and angels, disenchant nature, and reduce the ideal human activity solely to acts of pure intellection. One of the main concepts in Judaism adopted from Muslim and ultimately from Hellenistic philosophers is the cosmic Agent Intellect, understood in most of these traditions as the lowest of the ten separate intellects, which is sometimes envisioned in a hypostatic manner. ${ }^{48}$

Although this concept influenced many of the Maimonidean thinkers as well as the Kabbalist Abraham Abulafia, it played quite a marginal role in the main theosophical-theurgical schools of Kabbalah; even then, it was used in a different way conceptually. The Agent Intellect's constant intellectual activity reflects the intellectual activity of God on the one hand and serves as a form of ideal intellectual activity to be imitated by man on the other. Thus, what Aron Gurevitsch calls a "Gestalt-contexture" 49 has been generated. This Gestalt-contexture unifies the mentalistic understanding of God, that of his main intermediaries (the system of separate intellects, especially the last one, the Agent Intellect), the presence of the divine in nature, and the highest human activity, intellectual activity, into one broad continuum constituted by the intellectual element that permeates all levels of existence. I consider the consonance between the various significant aspects of reality and the resulting possibility for active human life to constitute a profound noetic structure that characterises both Maimonides's and Abulafia's thought.

This unifying concept was understood by Alexander of Aphrodisias, one of the major sources for medieval Neo-Aristotelianism and one of the main ancient commentators on Aristotle, to be a power that binds together the entire universe, which is understood as an organism whose different parts are permeated by a spiritual dimension. This view is found in a series of texts that are sometimes attributed to Alexander of Aphrodisias himself and sometimes to an ancient anonymous sage. It

48 See the important monograph by Herbert A. Davidson, Alfarabi, Avicenna, and Averroes on Intellect: Their Cosmologies, Theories of the Active Intellect, and Theories of Human Intellect (New York: Oxford University Press, 1992).

49 See Aron Gurwitsch, "Phenomenology of Perception: Perceptual Implications," in An Invitation to Phenomenology, ed. James M. Edie (Chicago: Quadrangle Books, 1965): 21; Idel, Hasidism: Between Ecstasy and Magic, 49, 111, 203, 272, note 15; Moshe Idel, “'Adonay Sefatay Tiftah': Models of Understanding Prayer in Early Hasidism,” Kabbalah 18 (2008): 106-7, note 265. 
cannot be found in the extant Greek sources, but it is found in Averroes, who puts forth the theory that there is an intellectual power that binds the entirety of reality. ${ }^{50}$

With such a view of the cosmos, the possibility of a union between the human intellect and the supernal intellectual powers, the Agent Intellect or God, is easier to understand. Needless to say, this emphatic approach to the centrality of mental operations as imitatio dei and the main religious ideal is alien to the Rabbinic emphasis on the performative aspects of religion.

Depending on the angle from which this concept is seen and the emphasis placed on one or more of the elements of this continuum, the connection between the three entities can imply a monotheistic, pantheistic, naturalistic, or anthropocentric religion. Moreover, these three processes also involve a much less voluntarist theology, which is an approach to nature where miracles become a quandary; that is, an approach that sees a human being as a composite that should suppress many aspects of his complex personality in order to allow the "best" form of human activity, intellection, to take place undisturbed.

Jewish philosophers or religious thinkers look for God not only in their religious life or in events in history, but also, and perhaps prominently, in the contemplation of nature, or, more precisely, in the contemplation of the constant mechanisms that operate in nature, the natural laws. The divinity is now conceived as being intimately related to both the permanent laws and the domain of the spiritual; the two realms are intertwined, although not as regards the voluntary acts of creation or the election of the people of Israel.

In more than one sense, the concept of God was naturalised and thus universalised. Either as a separate intellect, as the unmoved mover of the highest cosmic sphere, or as the First Cause, new concerns originally found in Greco-Hellenistic mental universes were adopted and disseminated in Jewish texts via the mediation

50 See the three commentaries on The Guide of the Perplexed, Rabbi Shem Tov ibn Falaquera, Moreh ha-Moreh, ed. Yair Shiffman (Jerusalem: World Union of Jewish Studies, 2001), 186. Also, under his influence, Rabbi Joseph ibn Kaspi, Maśkiyyot ha-Kesef, ed. S. Werbluner (Frankfurt am Main, 1848), reprinted in Šlošah Qadmonei Mefaršei ha-Moreh (Jerusalem: 1961), 74-75, and Rabbi Moses Narboni's Commentary on the Guide, in Der Commentar des Rabbi Moses Narbonensis, Philosophen aus dem XIV. Jahrhundert, zu dem Werke More Nebuchim des Maimonides, ed. Jakob Goldenthal (Vienna: K.K. Hof- und Staatsdruckerei, 1852), fol. 16b, all reflecting a view already adduced in Averroes; cf. Van den Bergh, Incoherence of Incoherence, 1:253-54; 2:143, note 254.2, which is a discussion that served as a major and perhaps the only conduit from the Greek sources of Jewish thought. In one of the discussions found in ibn Falaquera, this power is called "pre-eternal," qadmon, just as in Averroes' text. Whether or not this specific concept had already informed Maimonides's important discussion in the Guide of the Perplexed, 1:72, Pines, 187-89, where the entire world is seen as one organism, is a matter that deserves further investigation. For other influences of Alexander of Aphrodisias on Maimonides, see Pines's introduction to the Guide, 1:lxiv-lxxv. It is possible that this theory has something to do with the Stoic theme of the cosmos consisting in a universal sympathy. For a similar view in Abulafia's concept of natural powers as binding, see chapter 16, note 120 below. See also Idel, Studies in Ecstatic Kabbalah, 79-80, 87, note 36, and the version of this view found in the Theology of Aristotle, chapter 8. 
of Muslim philosophers and greatly impacted the theology of Jewish thinkers. This noetic core of philosophical religions does not include, however, a precise path to attaining the final noetic goal, but rather includes recommendations as to which philosophical books to study and encouragement to contemplate nature as a means of reaching the reflection of the divine. This lack of a definitive guideline for attaining union with the divine is the reason I conceive Maimonides's goal to be to provide a profound structure rather than a model that combines the ideal with a specific and elaborated path that leads towards the attainment of the divine.

In fact, Maimonides's Guide is not so much a systematic theology or treatise presenting a coherent philosophy as much as it is a mentalistic approach to religion that he imposes on a variety of earlier Jewish sources, especially biblical, by means of new and radical exegetical strategies unknown in the earlier classical versions of Judaism. The most important of Maimonides's approaches was the method of homonyms; namely, the claim that a word that does not fit the structure of the new religious worldview can be attributed a meaning that will resolve the quandary of a philosophically inclined exegete.

One of the main claims of this new sort of interpretation is that the scriptures have hidden aspects in the form of intellectual dimensions, a much broader strategy that I have called arcanisation. ${ }^{51}$ In this manner, religious texts have been imagined to contain secret layers related to the structure of nature and especially to the inner processes of man. Thus, the book of nature and the book of law are unified by the same assumption as to the existence of a shared hidden intellectual dimension, the intellectual or mental one, and the pursuit of the new type of religious man has been bifurcated into the categories of "scientific" and "exegetical." Moreover, these two paths should be followed at the same time.

This dramatic change generated by the emergence of the new philosophical religion is reflected in a poem written by a certain Abraham, who in my opinion may be identified with Abraham Abulafia. The poet writes: "Read the religion of the son of Amram, ${ }^{52}$ together with the religion of Moses the son of Maimon!" 53 Though these two religions (in both cases, the Hebrew term dat is used) are mentioned as if they are independent, both times, a Moses is mentioned either implicitly or explicitly. Moreover, the poet recommends that they should be studied together. ${ }^{54}$

51 See Moshe Idel, Absorbing Perfections: Kabbalah and Interpretation (New Haven/London: Yale University Press, 2002).

52 Namely, the biblical Moses.

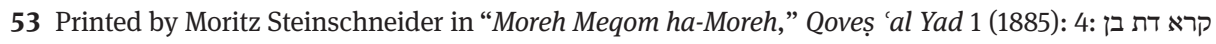
עמרם עם דת משה בן מימון.

The Hebrew term translated as "religion" is dat. On this poem being Abulafia's work, see Moshe Idel, “Abraham Abulafia's Works and Doctrine” [Hebrew] (PhD diss., Hebrew University, 1976), 34.

54 For the philosophical religion according to Maimonides and Rabbi Samuel ibn Tibbon, see James T. Robinson, "Maimonides, Samuel ibn Tibbon, and the Construction of a Jewish Tradition of Philosophy," in Maimonides after 800 Years: Essays on Maimonides and His Influence, ed. Jay M. Harris (Cambridge, MA: Harvard University Press, 2007): 291-306; Carlos Fraenkel, From Maimonides to Sa- 
In a way, this is another, perhaps even sharper formulation of the much more widespread dictum regarding Maimonides: "From Moses to Moses there was no one like Moses." This dictum emerged in the same period; namely, the second part of the thirteenth century. The poem's author puts the Mosaic religion alongside its medieval philosophical reform. Abulafia himself not only strove to synthesise the two forms (the Mosaic traditional form of Judaism and the Maimonidean mentalistic reform); he was also concerned with what I would call a linguistic reform of this synthesis.

Because of the influence of Muslim forms of Neo-Aristotelian philosophy, ${ }^{55}$ which were relatively new in Judaism and completely unknown to the Jews of some geographical areas such as Northern and Central Europe, Maimonides's Guide not only tremendously enriched Judaism, but it also disseminated some perplexity among his Rabbinic and more mythically oriented readers, both in his lifetime and afterwards. More than his earlier writings, where many of the new elements had already been introduced in order to reinterpret the classical forms of Judaism, The Guide of the Perplexed operated with a complex esoteric style in a rather weighty manner, which is the reason why the views that he wanted to keep under a veil of secrecy are now hardly understood much better than they were in his lifetime or in the Middle Ages, despite an entire century of vast, meticulous, and often fine scholarship in the field.

Following Shlomo Pines, we may describe Maimonides as someone who shifted from a somewhat more mystically oriented approach in his youth to a more sceptical

muel ibn Tibbon: The Transformation of the Dalālat al-Hāàirīn into the Moreh ha-Nevukhim [Hebrew] (Jerusalem: Magnes Press, 2007), 1-17, 40-53, and in English, his "From Maimonides to Samuel ibn Tibbon: Interpreting Judaism as a Philosophical Religion," in Traditions of Maimonideanism, ed. Carlos Fraenkel (Leiden: Brill, 2009): 177-211; Fraenkel, Philosophical Religions; James T. Robinson, "We Drink Only from the Master's Water: Maimonides and Maimonideanism in Southern France, 12001306," Studia Rosenthaliana 40 (2007-8): 27-60; and Zvi Diesendruck, "Samuel and Moses ibn Tibbon on Maimonides's Theory of Providence," HUCA 11 (1938): 341-66, and some of the studies to be referenced in the following notes. See also Lenn E. Goodman, "Maimonidean Naturalism," in Neoplatonism and Jewish Thought, ed. Lenn E. Goodman (Albany, NY: SUNY Press, 1992): 157-94 and Kenneth Seeskin, Searching for a Distant God: The Legacy of Maimonides (Oxford: Oxford University Press, 2000); see also Howard Kreisel, "Maimonides on Divine Religion," in Maimonides after 800 Years, 151-66.

55 For other significant types of influences on Maimonides, especially the Neo-Platonic or Ismā'iliyyah, see Shlomo Pines, "Shi'ite Terms and Conceptions in Judah Halevi's Kuzari," Jerusalem Studies in Arabic and Islam 2 (1980): 240-43, reprinted in his Collected Writings, vol. 5 (Jerusalem: Magnes Press, 1997): 245-47. See also Alfred L. Ivry's studies, especially his "Neoplatonic Currents in Maimonides' Thought," in Perspectives on Maimonides: Philosophical and Historical Studies, ed. Joel L. Kraemer (Oxford: Oxford University Press, 1991), 115-40; "Maimonides and Neoplatonism: Challenge and Response," in Neoplatonism and Jewish Thought, 137-55; "Islamic and Greek Influence on Maimonides's Philosophy," in Maimonides and Philosophy, 139-56; and "Isma'ili Theology and Maimonides's Philosophy," in The Jews of Medieval Islam: Community, Society, and Identity, ed. Daniel H. Frank (Leiden: Brill, 1995): 271-300. 
one in his later years. ${ }^{56}$ Given my approach to the understanding of Maimonides's thought as dynamic, as explicated in two of my studies mentioned in the last footnote, it is inacurate to speak about the Great Eagle's view as static or of him as having one single opinion, and even the inconsistency and contradictions he refers to in his expositions in The Guide of the Perplexed contribute to a more cautious approach to articulating his views.

It is possible to find a discussion in the Guide that became very important for Abulafia's anchoring of his linguistic exegetical technique in Maimonides himself, which has not yet attracted its due attention from scholars of the Great Eagle. ${ }^{57}$ I follow Pines's later view, which characterises Maimonides's later approach as rather sceptical towards the possibility of knowing the separate intellects and sees him as a thinker who was significantly influenced by the later phase of Al-Fārābī's thought as to the limitations of human knowledge of the metaphysical realm. ${ }^{58}$

Nevertheless, I would say that it would be too simplistic to adopt a homogenous description of Maimonides's thought as a whole, as, for example, his being purely a rationalist sceptic thinker or a philosophical mystic. I would assume that in his case, like in many others, we would do better to speak about what I call "conceptual fluidity"59-that is, a synchronic adoption of different views-or of diachronic changes of

56 See Shlomo Pines, "The Limitations of Human Knowledge according to al-Fārābī, ibn Bajja and Maimonides," in Studies in Medieval Jewish History and Literature, vol. 1, ed. Isadore Twersky (Cambridge, MA: Harvard University Press, 1979): 89-109, reprinted in Studies in the History of Jewish Thought, ed. Warren Zev Harvey, vol. 5, The Collected Works of Shlomo Pines (Jerusalem: Magnes Press, 1996): 404-31; Idel, "Sitre 'Arayot," 84-86; and Idel, "On Maimonides in Nahmanides and His School and Some Reflections," in Between Rashi and Maimonides: Themes in Medieval Jewish Thought, Literature and Exegesis, eds. Ephraim Kanarfogel and Moshe Sokolow (New York: Michael Scharf Publication Trust of the Yeshiva University Press, 2010): 131-64. See also Fraenkel, From Maimonides to Samuel ibn Tibbon, 191-92.

57 See Maimonides's pun on names related to the letters of the roots $H B L / B H L$ in the Guide of the Perplexed, 2:43, Pines, 2:392-93, described as a way to understand the secrets of the Torah, as discussed in Moshe Idel, "Abulafia's Secrets of the Guide: A Linguistic Turn," in Perspectives on Jewish Thought and Mysticism, eds. Alfred L. Ivry, Elliot R. Wolfson, and Allan Arkush (Amsterdam: Harwood Academic Publishers, 1998): 300-304. To Abulafia's sources discussed in this study as to Maimonides's combination of those letters, we should also add the discussions in Abulafia's Sefer Ge'ulah, ed. Raphael Cohen (Jerusalem: 2001), 38, and in Oșar 'Eden Ganuz, 1:2, 54. Both Maimonides's and Abulafia's discussions on these permutations require a more detailed analysis that cannot be achieved within this framework. See Yitzhak Tzvi Langermann, "On Some Passages Attributed to Maimonides" [Hebrew], in Me'ah She'arim, 225-27, and the view of Rabbi Joseph ibn Kaspi in Maśkiyyot ha-Kesef, 109-10.

58 See, for example, his most elaborated expressions of this approach in his "The Limitations of Human Knowledge according to al-Fārābī, ibn Bajja, and Maimonides," and "Les limites de la métaphysique selon al-Fārābī, ibn Bājja, et Maïmonide: sources et antithèses de ces doctrines chez Alexandre d'Aphrodise et chez Themistius," Miscellanea Mediaevalia 13 (1981): 211-25, reprinted in Studies in the History of Jewish Thought, 432-46.

59 For my application of this approach in some studies, see Hasidism: Between Ecstasy and Magic, 50-51; Ben, 337; "On the Identity of the Authors of Two Ashkenazi Commentaries to the Poem ha- 
opinion concerning the same topic in a person's career which generated the various evaluations. ${ }^{60}$

I do not mean to say that there is no profound structure that unifies the various stages of Maimonides's thought or distinguishes them from those of other thinkers; rather, in his specific case, those changes took place without any major transformation of the nature of Maimonides's entire conceptual structure, which is mainly based on Neo-Aristotelian noetics. No less important than general labels such as rationalist, sceptic, or mystic, ${ }^{61}$ highlighting the nature and directions of changes in his

Aderet we-ha-Emunah and the Concepts of Theurgy and Glory in Rabbi Eleazar of Worms"” [Hebrew], Kabbalah 29 (2013): 67-208; "Adonay Sefatay Tiftah"; "Prayer, Ecstasy, and Alien Thoughts in the Besht's Religious Worldview" [Hebrew], in Let the Old Make Way for the New: Studies in the Social and Cultural History of Eastern European Jewry Presented to Immanuel Etkes, Volume I: Hasidism and the Musar Movement, eds. David Assaf and Ada Rapoport-Albert (Jerusalem: Shazar Center, 2009): 57-120; "Mystical Redemption and Messianism in R. Israel Ba'al Shem Tov's Teachings," Kabbalah 24 (2011): 7-121; “The Kabbalah's 'Window of Opportunities,' 1270-1290,” in Me'ah She'arim, 185-91; “'The Land of Divine Vitality': Eretz Israel in Hasidic Thought” [Hebrew], in The Land of Israel in Modern Jewish Thought, ed. Aviezer Ravitzky (Jerusalem: Yad Ben Tzvi, 1998): 256-75; Mircea Eliade: From Magic to Myth, 4, 19-21; Primeval Evil: Totality, Perfection, and Perfectability in Kabbalah, especially in my concluding remarks (in preparation); and "Male and Female": Equality, Female's Theurgy, and Eros-Rabbi Moshe Cordovero's Dual Ontology (forthcoming). Also relevant are the studies of other scholars: Uriel Barak, "The Formative Influence of the Description of the First Degree of Prophecy in the Guide, on the Perception of 'the Beginning of the Redemption' by Rabbi A. I. Kook's Circle" [Hebrew], in Maimonides and Mysticism: Presented to Moshe Hallamish on the Occasion of His Retirement, eds. Avraham Elqayam and Dov Schwartz, Da'at 64-66 (2009): 403-4, note 125. See also Uri Safrai, “The Daily Prayer Intention (Kavvanot) according to Rabbi Isaac Luria” [Hebrew], Da'at 77 (2014): 145 and note 6. My resort to "conceptual fluidity" differs from the recurrent resort to concidentia oppositorum and paradoxical statements that have permeated scholarship on Kabbalah and Hasidism since Scholem, which generates a paradoxical type of scholarship.

60 See Yitzhak Tzvi Langermann's important discussion in "Maimonides and Miracles: the Growth of a (Dis)belief," Jewish History 18 (2004): 147-72. Langermann maps another instance of development in Maimonides's thought, one shifting from a sceptical attitude towards miracles towards a more openminded attitude to their possibility. See also Gad Freudenthal, "Maimonides on the Scope of Metaphysics alias Ma'aseh Merkavah: The Evolution of His Views," in Maimónides y su época, eds. Carlos del Valle Rodríguez, Santiago García-Jalón de le Lama, and Juan Pedro Monferrer Sala (Madrid: Sociedad Estatal de Conmemoraciones Culturales, 2007): 221-30.

61 For scholarly views of Maimonides as a mystic, see David R. Blumenthal, "Maimonides's Intellectualist Mysticism and the Superiority of the Prophecy of Moses,” Studies in Medieval Culture 10 (1981): 51-77; Blumenthal, Philosophic Mysticism: Studies in Rational Religion (Ramat-Gan: Bar-Ilan University Press, 2006); Hannah Kasher, "Mysticism within the Confines of Reason Alone" [Hebrew], in Maimonides and Mysticism, 37-43; Shaul Regev, "Prophecy in Maimonides's Philosophy-Between Rationalism and Mysticism" [Hebrew], in Maimonides and Mysticism, 45-55; Gideon Freudenthal, "The Philosophical Mysticism in Maimonides" [Hebrew] in Maimonides and Mysticism, 77-97; Menachem Lorberbaum, "Mystique mythique et mystique rationelle," Critique 728-729 (2008): 109-17, Idel, "On Maimonides in Nahmanides and His School." For views of other Maimonideans as mystics, see Joseph B. Sermoneta, "Rabbi Judah and Immanuel of Rome: Rationalism Whose End Is Mystical Belief” [Hebrew], in Revelation, Faith, Reason, eds. Moshe Halamish and Moshe Schwartz (Bar-Ilan Uni- 
thought can illuminate our understanding of the significance of his discussions. Such an approach differs significantly from the main type of presentation of authors belonging to Jewish thought, philosophy, and Kabbalah as reflecting ways of thought that are imagined as being, conceptually speaking, more homogenous. ${ }^{62}$ To offer an example of my more complex reading: the very title of the Guide deals, in my opinion, with two different topics: the guidance is mainly Neo-Aristotelian, dealing as it does with the more general philosophical worldview, while the alleged perplexity, which is merely one that Maimonides creates, is of a Platonic nature, as Strauss claimed, as it opens new questions in Judaism in ways reminiscent of the allegorical interpretations of ancient myths that disestablished the status of traditional religious truths. Those discrepancies and complexities are not just a matter of divergences between legalistic versus philosophical sorts of writings, but can be discerned even in the same treatise.

By opening a new line in Jewish thought that was embraced by many Jewish thinkers in the Middle Ages, and even much later in Jewish theology in general, Maimonides's specific form of understanding earlier Jewish esotericism-known by the term Sitrei Torah, ${ }^{63}$ "the secrets of the Torah"-either in its Rabbinic forms or that found in the Hekhalot literature, ${ }^{64}$ prompted a reaction among early Kabbalists who conceived his philosophical interpretations of these secrets to be illegitimate innovations. Instead, they offered their diverging interpretations. ${ }^{65}$ Though a marginal impact of some of the Great Eagle's philosophical phrases and themes can be discerned in some Kabbalistic views in books written before 1270, the main lines of Kabbalistic thought moved in directions that were conceptually different from that of Maimonides's thought and they developed literary genres that did not depend on those used by Maimonides. In a way, they are rather antithetical to Maimonides. ${ }^{66}$

versity Press, Ramat-Gan, 1976): 54-70. See also Adam Afterman, “And They Shall Be One Flesh”: On the Language of Mystical Union in Judaism (Leiden: Brill, 2016), 102-20.

62 Moshe Idel, "On the Theologization of Kabbalah in Modern Scholarship," in Religious Apologetics -Philosophical Argumentation, eds. Yossef Schwartz and Volkhard Krech (Tübingen: Mohr Siebeck, 2004): 123-74.

63 See Klein-Braslavy, King Solomon and Philosophical Esotericism, or Idel, "Sitre 'Arayot."

64 See Idel, "The Concept of the Torah in Hekhalot Literature."

65 See Idel, "Maimonides and Kabbalah," in Studies in Maimonides, 31-81.

66 See Alexander Altmann, "Maimonides's Attitude toward Jewish Mysticism," in Studies in Jewish Thought, ed. Alfred Jospe (Detroit: Wayne State University Press, 1981): 200-219; Charles Mopsik, Chemins de la cabale: vingt-cinq études sur la mystique juive (Tel Aviv/Paris: Éclat, 2004), 48-54; Shlomo Blickstein, "Between Philosophy and Mysticism: A Study of the Philosophical-Qabbalistic Writings of Joseph Giqatila (1248-c. 1322)” (PhD diss., Jewish Theological Seminary of America, 1984); Elliot R. Wolfson, "Beneath the Wings of the Great Eagle: Maimonides and Thirteenth-Century Kabbalah," in Moses Maimonides (1138-1204): His Religious, Scientific, and Philosophical "Wirkungsgeschichte" in Different Cultural Contexts, eds. Görge K. Hasselhoff and Otfried Fraisse (Würzburg: Ergon Verlag, 2004): 209-37; Wolfson, “The Impact of Maimonides' Via Negativa on Late Thirteenth Century Kabbalah," in Maimonidean Studies 5 (2008): 393-442; Boaz Huss, "Mysticism versus Philosophy in Kabbalistic Literature,” Micrologus 9 (2001): 125-35; Sara O. Heller-Wilensky, “The Dialectical 
Maimonides's name or writings were only rarely explicitly referenced by early Kabbalists writing before 1270. One exception can be found in an epistle of Rabbi Ezra of Gerona, who quoted a line from the Guide ${ }^{67}$ that contains nothing especially Maimonidean. More substantially, Nahmanides approvingly quoted a lengthy, mystically oriented passage from Maimonides's Commentary on the Mishnah; given its content, the passage could have been influential on Nahmanides's spiritual eschatology. ${ }^{68}$

The rather scant amount of references to Maimonides, who was the main centre of debates and discussions among European Jewry in the first half of the thirteenth century, is a surprising fact that should be put into relief because it displays the low importance his thought had in the conceptual economy of the theosophical Kabbalists. In one of these few instances, a longer quotation was given so that the Kabbalist could oppose his views. ${ }^{69}$ From this point of view, Maimonides served as a negative trigger whose mentalist and naturalistic approaches to religion ${ }^{70}$ challenged some

Influence of Maimonides on Isaac ibn Latif and Early Spanish 'Kabbalah”' [Hebrew], Jerusalem Studies in Jewish Thought 7 (1988): 289-306; and Menachem Lorberbaum, Dazzled by Beauty: Theology as Poetics in Hispanic Jewish Culture [Hebrew] (Jerusalem: Ben-Zvi Institute for the Study of Jewish Communities in the East, 2011), 51-121.

67 See Wolfson, "Beneath the Wings of the Great Eagle," 222.

68 See Idel, "On Maimonides in Nahmanides and His School," and Afterman, "And They Shall Be One Flesh," 102-29.

69 See the text by Rabbi Jacob Ben Sheshet that was translated and discussed in Moshe Idel, "Maimonides's Guide of the Perplexed and the Kabbalah," Jewish History 18 (2004): 199-201, and Moshe Idel, "Jewish Kabbalah and Platonism in the Middle Ages and Renaissance," in Neoplatonism and Jewish Thought, 338-44. In Ben Sheshet’s Mešiv Devarim Nekhoḥim, ed. Georges Vajda (Jerusalem: Israel Academy of Sciences and Humanities, 1968), he refers to Maimonides's book several times while taking issue with Rabbi Samuel ibn Tibbon's Ma'amar Yiqawwu ha-Mayyim. See also Jonathan Dauber, "Competing Approaches to Maimonides in Early Kabbalah," in The Cultures of Maimonideanism: New Approaches to the History of Jewish Thought, ed. James T. Robinson (Leiden: Brill, 2009): 57-88. None of the theosophical Kabbalists in the thirteenth century wrote even a neutral Kabbalistic commentary on Maimonides's philosophical texts, nor an extensive exposition on his views. In my opinion, Maimonides was of negligible importance to the theosophical Kabbalists, especially when compared to his centrality in Abulafia's works. In the case of most of the theosophical Kabbalists, the role played by Maimonides is essentially that of a negative trigger, though in its detailed themes this had a negligible impact. Especially interesting is the fact that Maimonides's enumeration of the $613 \mathrm{com}$ mandments in his Sefer ha-Mitzwot was sometimes accepted by Kabbalists, although they never mentioned his name in that context.

70 For some general surveys of Maimonides's novel concept of true religion-namely, of Judaism as he understood it-see David Hartman, Maimonides: Torah and Philosophical Quest (Philadelphia: Jewish Publication Society, 1976); Eliezer Goldman, Expositions and Inquiries: Jewish Thought in Past and Present [Hebrew], eds. Avraham Sagi and Daniel Statman (Jerusalem: Magnes Press, 1996), 60-137; Isadore Twersky, Introduction to the Code of Maimonides (Mishneh Torah) (New Haven: Yale University Press, 1980); Joel L. Kraemer, "Naturalism and Universalism in Maimonides' Political and Religious Thought," in Me'ah She'arim, 47-81; Ravitzky, History and Faith, 146-303; Amos Funkenstein, Nature, History, and Messianism in Maimonides [Hebrew] (Tel Aviv: Open University, 1983); Davidson, Moses Maimonides, The Man and His Works, 377-87; Davidson, Maimonides the Rationalist (Oxford: Littman 
segments of the Jewish elite in Western Europe to offer alternatives to his theories. Indeed, his interpretation of Jewish esoteric matters was one of the main reasons for the emergence of theosophical-theurgical Kabbalah as an articulation of earlier themes in a wider framework. ${ }^{71}$ Seen in its entirety, the thirteenth-century theosophical-theurgical Kabbalah includes some faint echoes of Maimonides's thought, in a negative parallel to the intensity and depth of appropriation that is evident in Abulafia's Kabbalah.

Let me provide an example of such a challenge. In the introduction to his widespread Commentary on Sefer Yeșirah, Rabbi Joseph ben Shalom Ashkenazi, an important Kabbalist active sometime at the end of the thirteenth century, ${ }^{72}$ wrote in a rather fascinating manner about the eschatology of the philosophers who located the main act of redemption in the intellect and not in the soul: "You should know that to those who are going to interpret the Torah according to the way of nature and say that the intellect cleaved to God, this is no more than a joke and a theft, an attempt to steal the minds of the sons of religion." ${ }^{\prime 3}$ The nexus between the "way of nature" and the

Library of Jewish Civilization, 2011); Jose Faur, Homo Mysticus: A Guide to Maimonides's Guide for the Perplexed (Syracuse: Syracuse University Press, 1999); Kellner, Maimonides' Confrontation with Mysticism; Ehud Benor, Worship of the Heart: A Study in Maimonides's Philosophy of Religion (Albany, NY: SUNY Press, 1995); Fraenkel, Philosophical Religions, 175-202; Eliezer Hadad, The Torah and Nature in Maimonides's Writings [Hebrew] (Jerusalem: Magnes Press, 2011); and Moshe Halbertal, Maimonides: Life and Thought, trans. Joel Linsider (Princeton: Princeton University Press, 2013).

71 Idel, "Maimonides and Kabbalah."

72 This text, widespread in manuscript and in print, has been attributed to the twelfth-century Rabbi Abraham ben David of Posquières. For the real author, see the ground-breaking study by Gershom Scholem, "The Real Author of the Commentary on Sefer Yeșirah Attributed to Rabbi Abraham ben David and His Works" [Hebrew], in Studies in Kabbalah [1], eds. Joseph ben Shlomo and Moshe Idel (Tel Aviv: Am Oved, 1998): 112-36.

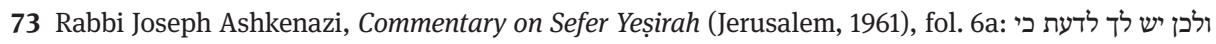
ההולכים לפרש התורה ע"ד טבע ואומרים כי השכל נדבק בשם, אין זה רק היתול וגנבה שגונבים דעת בני הדת.

For a different understanding of the cleaving of the soul, see Ashkenazi, fol. 9cd, and his Commentary on Genesis Rabbah, ed. Moshe Hallamish (Jerusalem: Magnes Press, 1984), 269. This Kabbalist was certainly aware of Maimonides's book, and formulations found in some of his few statements show that from some points of view, he was close to Abulafia, though his Kabbalah was radically different from that of the ecstatic Kabbalist. On this Kabbalist and his type of Kabbalah, see Haviva Pedaya, "Sabbath, Sabbatai, and the Diminution of Moon: The Holy Conjunction, Sign and Image" [Hebrew], in Myth in Judaism, ed. Haviva Pedaya (Be'er-Sheva: Ben-Gurion University Press, 1996): 150-53; Brian Ogren, Renaissance and Rebirth: Reincarnation in Early Modern Italian Kabbalah (Leiden: Brill, 2009), 18-21, 187, 193-94, 216-19, 279-80; Moshe Idel, "An Anonymous Commentary on Shir ha-Yihud," in Mysticism, Magic and Kabbalah in Ashkenazi Judaism, eds. Karl Erich Grözinger and Joseph Dan (Berlin: De Gruyter, 1995): 151-54; Moshe Idel, Golem: Jewish Magical and Mystical Traditions on the Artificial Anthropoid (Albany, NY: SUNY Press, 1990), 119-26; Moshe Idel, Enchanted Chains: Techniques and Rituals in Jewish Mysticism (Los Angeles: Cherub Press, 2005), 228-32; Moshe Idel, “Ashkenazi Esotericism and Kabbalah in Barcelona," Hispania Judaica Bulletin 5 (2007): 100104, and my more recent Saturn's Jews, as well as Vajda's important study referenced in note 79 below. 
"cleaving to God" is of the utmost importance for understanding Abulafia's general approach, as will be discussed below. ${ }^{74}$

The intellectual cleaving is conceptualised as a natural phenomenon and understood in a negative light. Moreover, we learn here about attempts to propagate this view. Elsewhere, in a parallel statement found in another of Ashkenazi's books, he adds that those commentators connected their naturalistic interpretation to a view of the world as pre-eternal ('al ha-qadmut). ${ }^{75} \mathrm{Here}$, the intellectual and natural understandings of the sacred scriptures, envisioned by Ashkenazi as deleterious, were imagined to go hand in hand, since the intellect was conceived as part of nature when understood in an Aristotelian vein. A person is capable of educating her- or himself in order to attain the intellectual overflow, as it is available since it is constantly pulsating in reality. Ashkenazi presents the philosophical ideal of the intellect's union with God, which is found, though only implicitly among those commentators, to be a mere strategy to attract religious persons to the study of philosophy. This strategy of disguise was recognised by both Abraham Abulafia himself and by Rabbi Solomon ibn Adret in his description of the special nature of Abulafia's books. $^{76}$

Ashkenazi's accusation is corroborated by the writing of one of his contemporaries. Rabbi Judah Romano, an Italian thinker active in Rome at the beginning of the fourteenth century, writes in his Commentary of the Account of Creation: "Some of the sages of Israel in the last generation-whose names it would be better not to mention -were inclined to an interpretation of pre-eternity in their commentaries on the order of creation and to the syllogisms of the philosophers."77 As we shall also see

74 See below, pp. 234, 255.

75 Ashkenazi, Commentary on Genesis Rabbah, 250:

אלא שגם קמו בעדתנו אנשים נקראו חכמים בעיני מי שאינו יודע דתו וסבור שעלתה בידו אמונתו והנם מפרשי התורה על

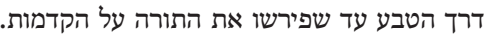

"But in our community appeared persons who are called 'sages' by the one who does not know what his religion is but thinks he understands his faith, and they are commenting on the Torah in accordance with the path of nature, so that they will comment on the Torah according to pre-existence." See also his similar claim in an important discussion found elsewhere in the same book, 146:

לקיים הקדמות ועשו מלות בדואות בפשטים כל אחד ואחד כדי לישב הדת על מאמיני הפכה בקדמות העולם.

“To sustain the pre-eternity, and they invented words for the plain sense, each and every one in order to settle religion according to the believers of its opposite, the pre-eternity of the world." The "invented words" may refer to allegories that interpret the plain sense. See also the view that Nahmanides attributes to a certain Rabbi Abraham, perhaps ibn Ezra, as to a Platonic view of pre-eternity, to be adduced below at the end of chapter 18.

76 See ibn Adret's responsum 1, no. 548, and Rabbi Nathan, Le Porte della Giustizia, 478.

77 Ms. Firenze, Laurenziana, Plut. I, 22, fol. 45a:

אבל קצת מחכמי ישראל האחרונים אשר אין ראוי לנקבם בשמות, נטו אל הקדמות וביארו בפירושיהם כל סדר הבריאה ביאור נוטה אל הקדמות נמשכים אחר הקרי השי הפרי הפילוסופים.

On this treatise, see Joseph B. Sermoneta, “The Commentary to 'The Pericope of Creation' of Rabbi Judah Romano and Its Sources" [Hebrew], in Proceedings of the World Congress of Jewish Studies 2 (1965): 341-42. 
in the case of Abulafia, Romano's main concern was not with philosophy per se, but rather an attempt to reinterpret traditional Jewish religion in a new way, though his approach differs quite substantially from that of the earlier Rabbi Samuel ibn Tibbon. We have recently learned from Yitzhak Tzvi Langermann's discussion of the earlier Jewish exegetical material that there were indeed earlier commentators on Genesis who assumed the pre-eternity of the universe. ${ }^{78}$

Joseph Ashkenazi was certainly quite critical of philosophers, although he was also influenced by them: his writings display a good acquaintance with medieval philosophy. ${ }^{79}$ Though he resorts to the term "nature" many times, he nevertheless claimed that nature does not have a grasp on the people who are close to God. ${ }^{80}$ Ashkenazi offered a comprehensive Kabbalistic picture of the universe based on nonMaimonidean ways of thought, some probably stemming from the Ismā îliyyah, ${ }^{81}$ which were at least in part formulated as a response to the philosophical challenge, grounded in a naturalistic approach. ${ }^{82}$ He eventually used Maimonidean themes within an anti-Maimonidean approach, as duly pointed out by Georges Vajda. ${ }^{83} \mathrm{~A}$ commentator on some Psalms ${ }^{84}$ and several late antique Jewish texts, ${ }^{85}$ Joseph Ashkenazi was more concerned with the fallacies of philosophical hermeneutics than any other thirteenth-century Kabbalist, at least insofar as we can learn from written testimonies.

I have offered and will continue to refer to these examples from his writings because Ashkenazi was critical of some philosophical issues that were treated positive-

78 Yitzhak Tzvi Langermann, "Cosmology and Cosmogony in Doresh Reshumot, a Thirteenth-Century Commentary on the Torah,” HTR 97 (2004): 199-227. See also Abulafia, Sitrei Torah, ed. Gross (Jerusalem: 2002), 175-76. Compare also to the remnant of the lost commentary on the Pentateuch by Rabbi Shem Tov ibn Falaquera, presented by the fourteenth-century Rabbi Samuel ibn Tzartza, discussed in Raphael Jospe and Dov Schwartz, "Shem Tov Falaquera's Lost Bible Commentary," HUCA 64 (1993): 191, as well as his other discussions cited on 172-73.

79 See the important article by Georges Vajda, "Un chapitre de l'histoire du conflit entre la Kabbale et la philosophie: la polémique anti-intellectualiste de Joseph b. Shalom Ashkenazi," Archives d'histoire doctrinale et littéraire du Moyen Âge 31 (1956): 45-14, as well as the text he printed dealing with his critique of philosophy, "Ninety-Four Principles of the Philosophers Cited by Rabbi Joseph Ashkenazi” [Hebrew], Tarbiz 27 (1958): 290-300.

80 Commentary on Sefer Yeșirah, fol. 44d:

כי דורשי ה' לא יפעל בהם טבע רק "ה' עליהם יחיו" (ישעיה לח:יז). It should be pointed out that other Kabbalists also expressed their reticence towards the centrality of the concept of nature in the writings of philosophers. See especially Nahmanides's views as addressed in chapter 18 below.

81 See the important observations of Shlomo Pines to this effect in his "Shi'ite Terms and Conceptions in Judah Halevi's Kuzari,” 249-51.

82 See the passage by Nahmanides about Maimonides's emphasis on nature versus miracles in chapter 18 below.

83 See his "Un chapitre de l'histoire du conflit," 73-74.

84 See Moshe Hallamish, "Remnants of the Commentary of Rabbi Yoseph Ashkenazi to Psalms" [Hebrew], Da'at 10 (1983): 57-70.

85 See Hallamish's introduction to Commentary on Genesis Rabbah, 14-16. 
ly by Abulafia. This parallelism shows an antithetical relationship between two forms of Kabbalah that were acquainted with the same philosophical sources. Their exponents nevertheless took divergent paths; perhaps there is also some kind of silent polemic present in these forms. Though he was indubitably a theosophical Kabbalist, the profound structure of Ashkenazi's Kabbalah differs quite substantially from that of the other theosophical-theurgical Kabbalists, ${ }^{86}$ just as his thought differs from Abulafia's ecstatic Kabbalah, though there are some details that may point to a form of acquaintance with Abulafia's practice. ${ }^{87}$

However, other Kabbalists who espoused views very different from those of Maimonides were much less outspoken than Rabbi Joseph Ashkenazi. This implicit reaction is part of what I have called a silent controversy concerning the Great Eagle's thought, especially his interpretations of Rabbinic esotericism. ${ }^{88}$ Thus, we may see a considerable variety of attitudes towards the Great Eagle in Abulafia's generation, some of which are part of a dialogue with Maimonides and others of which are representative of frictions between their views and his.

Maimonides's universalist approach (and that of his philosophical sources) and his strong propensity to naturalise religion polarised Jewish thought. On the one hand, it induced more radical interpretations of Judaism in terms that Maimonides was careful not to explicate or elaborate; these more radical interpreters include several thirteenth- and fourteenth-century Jewish philosophers, whom we shall designate in the following as the Maimonideans. On the other hand, it triggered the elaborations of theosophical systems based on what may be called positive attributes as a response to his claims. ${ }^{89}$ The difference between these two moves is not just a matter of specific understandings of the same topic, but also of the main themes that the two speculative moves adopted and elaborated. So, for instance, some of the Maimonidean thinkers were concerned with the Great Eagle's theory of prophecy in more general terms than Maimonides's discussions provide. This is the case, for example, for Rabbi Zerahyah Ḥen, Rabbi Levi ben Abraham, Isaac Albalag, Judah Moses ben Daniel Romano, Isaac Polqar, and Gersonides. This topic is also quintessential for Abulafia's own concerns. ${ }^{90}$

86 See, for the time being, Moshe Idel, "The Meaning of 'Ta'amei Ha-'Ofot Ha-Teme'im' by Rabbi David ben Judah he-Hasid" [Hebrew], in 'Alei Šefer: Studies in the Literature of Jewish Thought Presented to Rabbi Dr. Alexander Safran, ed. Moshe Hallamish (Ramat-Gan: Bar-Ilan University Press, 1990): $11-27$.

87 See Scholem, "The Real Author," 115.

88 See Idel, "Maimonides and Kabbalah."

89 See also Moshe Idel, "Divine Attributes and Sefirot in Jewish Theology" [Hebrew], in Studies in Jewish Thought, eds. Sara O. Heller-Willensky and Moshe Idel (Jerusalem: Magnes Press, 1989): 87112, and Idel, "Maimonides and Kabbalah."

90 See Howard Kreisel, Prophecy: The History of an Idea in Medieval Jewish Philosophy (Dordrecht: Kluwer, 2001), 148-423; Kreisel, "The Verification of Prophecy in Medieval Jewish Philosophy" [Hebrew], JSJT 4 (1984): 1-18; Kreisel, "Sage and Prophet in the Thought of Maimonides and His Followers" [Hebrew], Eshel Ber Sheva 3 (1986): 166-69; Kreisel, "Prophetic Authority in the Philosophy of 
This interest in prophecy was to a great extent triggered by the falāsifah's discussions, especially those of Al-Fārābī, who supplied Maimonides with the basic terms for his philosophical definition of the nature of biblical prophecy. ${ }^{91}$ The emphasis on the importance of this topic differs from Rabbinic religiosity as well as from early theosophical Kabbalists, whose references to prophecy are quite scant and conceived as being related to the ascent and cleaving to hypostatic divine powers. The only theosophical Kabbalist who expatiated on prophecy in a manner different from Maimonides was the abovementioned Rabbi Joseph Ashkenazi, who was of Ashkenazi extraction. ${ }^{92}$

Spinoza and in Medieval Jewish Philosophy" [Hebrew], in Spiritual Authority: Struggles over Cultural Power in Jewish Thought, eds. Howard Kreisel, Boaz Huss, and Uri Ehrlich (Be'er-Sheva: Ben-Gurion University Press, 2009): 207-21; Kreisel, "The Prophecy of Moses in Medieval Jewish Provençal Philosophy: Natural or Supernatural?” [Hebrew], in Judaism as Philosophy: Studies in Maimonides and the Medieval Jewish Philosophers of Provence (Boston: Academic Studies Press, 2015): 179-204; Kreisel, "The Land of Israel and Prophecy in Medieval Jewish Philosophy" [Hebrew], in The Land of Israel in Medieval Jewish Thought, eds. Moshe Halamish and Aviezer Ravitzky (Jerusalem: Ben-Zvi Institute, 1991): 40-51; Hannah Kasher, "Disciples of Philosophers as 'Sons of the Prophets' (Prophecy Manuals among Maimonides's Followers)" [Hebrew], JSJT 14 (1998): 73-85; Shlomo Pines, “Some Views Put Forward by the 14th-Century Jewish Philosopher Isaac Pulgar, and Some Parallel Views Expressed by Spinoza" [Hebrew], in Studies in Jewish Mysticism, Philosophy, and Ethical Literature Presented to Isaiah Tishby on His Seventy-Fifth Birthday, eds. Joseph Dan and Joseph Hacker (Jerusalem: Magnes Press, 1986): 420-26; Dov Schwartz, "On the Concepts of Prophecy of Rabbi Isaac Pulgar, Rabbi Shlomo Al-Qonstantini and Spinoza" [Hebrew], Assufot 4 (Jerusalem: 1990): 57-72; Joseph B. Sermoneta, "Prophecy in the Writings of R. Yehudah Romano," in Studies in Medieval Jewish History and Literature, vol. 2, ed. Isadore Twersky (Cambridge, MA: Harvard University Press, 1984): 337-74; Aviezer Ravitzky, "The Thought of R. Zerahyah ben Isaac ben She'altiel Ḥen and Maimonidean-Tibbonian Philosophy in the 13th Century" (PhD diss., Hebrew University, 1977) [Hebrew], 273-86; Barry Mesch, Studies in Joseph ibn Caspi (Leiden: Brill, 1975), 60-106; Abraham J. Heschel, Prophetic Inspiration after the Prophets: Maimonides and Other Medieval Authorities, ed. Morris M. Faierstein (Hoboken, NJ: Ktav Publishing House, 1996); Menachem Kellner, "Maimonides and Gersonides on Mosaic Prophecy," Speculum 52 (1977): 62-79; and Sarah Stroumsa, "Prophecy versus Civil Religion in Medieval Jewish Philosophy: The Case of Judah Halevi and Maimonides," in Tribute to Michael: Studies in Jewish and Muslim Thought Presented to Professor Michael Schwarz, eds. Sara Klein-Braslavy, Binyamin Abramov, and Joseph Sadan (Tel Aviv: Tel Aviv University, 2009): 79-102. Of special interest is the lengthy discussion of prophecy in Levi ben Avraham, Liwyat Hen: The Quality of Prophecy and the Secrets of the Torah [Hebrew], ed. Howard Kreisel (Be'er-Sheva: Ben-Gurion University Press, 2007). See also Isaac Albalag's Sefer Tiqqun ha-De'ot, ed. Georges Vajda (Jerusalem: Israel Academy of Sciences and Humanities, 1973), 82-83, as well as Paul Fenton, "A Mystical Treatise on Perfection, Providence and Prophecy from the Jewish Sufi Circle," in The Jews of Medieval Islam, 301-34.

91 Richard Walzer, Greek into Arabic: Essays on Islamic Philosophy (Oxford: Bruno Cassirer, 1962), 206-19.

92 See Idel, Enchanted Chains, 228-32. See also my "Prophets and Their Impact in the High Middle Ages: A Subculture of Franco-German Jewry," in Regional Identities and Cultures of Medieval Jews, eds. Javier Castano, Talya Fishman, and Ephraim Kanarfogel (London: Littman Library of Jewish Civilization, 2018): 285-338. 
The Maimonidean line of thought was continued later on, and one of its last major metamorphoses in this chain of thinkers can be found in Baruch Spinoza, who was also the greatest philosophical critic of the Great Eagle's theory of religion. ${ }^{93}$ What seems to unify these Maimonidean authors in contrast to Maimonides himself is the acceptance of his general naturalist understanding of religion while often ignoring the esoteric strategy employed in the Guide. By commenting on the Guide, most of them implicitly or explicitly removed the esoteric veil found in the interpreted text. Though this is also the case with Abulafia, he nevertheless remained closer to the esotericism in the Guide by retaining some important aspects of Maimonides's technique of hiding, without, however, any critique addressed to the Great Eagle, as is most obviously found in Spinoza.

However, this naturalisation of religion also generated the articulation of opposing views, especially among the theosophical-theurgical Kabbalists who were more particularist than in earlier Jewish thought, Rabbi Judah ha-Levi aside. In other words, we witness a gradual polarisation of conceptual camps within the thirteenth-century European Jewish elites which would become parts of belligerent factions in the controversies over Maimonides's writings.

To be sure, Maimonides and the Maimonideans were not the sole factor that contributed to this polarisation in Jewish thought that created the more pronounced mythical literatures, since the Hebrew translations of the writings of Averroes, as well as the growing Latin scholastic literature in Italy and Western Europe, could also have contributed to a reaction against philosophy and the philosophical understanding of religion. In any case, an example of such early polarisation seems to be the case of Jacob ben Sheshet's reaction to Rabbi Samuel ibn Tibbon's treatise Yiqawwu ha-Mayyim. However, the Great Eagle and his many followers among the Provençal and Spanish thinkers, whose names we will mention very shortly, were indubitably the most decisive factor in this complex process of restructuring undertaken by some European Jewish elites.

By portraying a more organised and stable universe-the Greek cosmos, which has a physis, a stable nature-medieval Muslim, Christian, and Jewish philosophers were inclined to reduce the role that traditional religious activity could play, or, in the case of the Jews, the theurgical aspects of the commandments as formulated in some Rabbinic dicta, the literature of the Ashkenazi Hasidism, and the main schools of Kabbalah. Let me emphasise here that the game of hinting at secrets opens the gate to a variety of interpretations for better or worse, a well-known phenomenon in studies of Maimonides. ${ }^{94}$ It also allows for a gradual radicalisation of what the

93 See Warren Zev Harvey, "Portrait of Spinoza as a Maimonidean,” Journal of the History of Philosophy 19 (1981): 151-72; Leo Strauss, Spinoza’s Critique of Religion (New York: Schocken, 1982), 147-92; Fraenkel, Philosophical Religions, 213-81; and Alexander Even-Hen, "Maimonides's Theory of Positive Attributes” [Hebrew], Da'at 63 (2008): 41-45. See also Appendix C, note 136 below.

94 See Kellner, Maimonides’ Confrontation with Mysticism, 16, note 43. 
Maimonideans guessed were the master's hidden thoughts, be they genuine or spurious.

\section{The Early Maimonideans}

In this chapter, I am concerned with situating some major aspects of the thought of the Kabbalist Rabbi Abraham Abulafia within the Maimonidean tradition. Abulafia's thought is one of the many varieties of Jewish thought that depends on the Great Eagle's books; it is related to subsequent developments in what can be called the broader phenomenon of Maimonideanism, especially the Averroistic interpretations of Maimonides's thought. In this book, I will explore four major issues: 1) the Maimonidean tradition; 2) Abulafia's testimonies as to his study of The Guide of the Perplexed and other philosophical books, as well as his teaching of the Guide in a variety of places in Europe; 3) some esoteric issues related to his thought and activity; and 4) the presentation and analysis of Abulafia's parable of the pearl as an allegory for the true religion. I will also discuss his interpretations by elucidating some key issues in his writings that pertain to those interpretations. The five appendices will deal with issues that are less concerned with esotericism.

My analysis of the above material should be seen within the wider framework of the transmission of knowledge (translatio scientiae) from the Middle East to Europe at the end of the first millennium of the common era and the complex developments that occurred afterwards. This broad phenomenon was delineated by Moses Gaster, though with quite vague lines, at the end of the nineteenth century; his views constitute an insight, unduly forgotten in scholarship, for understanding some aspects of the emergence and evolution of European culture in general and Jewish culture specifically. ${ }^{95}$ We may see this insight in terms of the stream of traditions that resort to scholarly descriptions of the transmission of ancient Mesopotamian religions.

Medieval Jewish philosophy, which began outside Europe, mainly in Iraq and some parts of Northern Africa, was quickly transferred to the southern countries of Europe; there, it began its rapid development as part of the larger phenomenon of the transmission of Greek and Hellenistic philosophies, mostly through the mediation of Christian and Muslim translators and seminal Muslim thinkers. The Neo-Ar-

95 See Moses Gaster, Ilchester Lectures on Greeko-Slavonic Literature (London: Trübner \& Co., 1887) and Moses Gaster, Literatura populară română, ed. Mircea Anghelescu (Bucharest: Minerva, 1983). On his views of Jewish mysticism in general, see Moshe Idel, "Moses Gaster on Jewish Mysticism and the Book of the Zohar" [Hebrew], in New Developments in Zohar Studies, ed. Ronit Meroz, 111-27. For a massive survey of many issues that are pertinent to Gaster's general scheme, see the recent analyses of the arrival of the dualistic theories from the East to Western Europe by Yuri Stoyanov, The Other God: Dualist Religions from Antiquity to the Cathar Heresy (New Haven: Yale University Press, 2000), 65-123. See also Shulamit Laderman, Images of Cosmology in Jewish and Byzantine Art: God's Blueprint of Creation (Leiden: Brill, 2013). 
istotelian trend is just one of several developments, though indubitably the main one, that changed the intellectual landscape of medieval Europe, especially from the thirteenth century. In addition, in the case of Jewish culture, a broad variety of other genres of literature was transmitted: Rabbinic, magic, and Hekhalot literature, along with liturgical poetry, made their ways, by paths and channels that are scarcely known, to the southern shores of Europe and laid the foundation of the variety of Jewish cultures there.

However, none of these literatures was as dramatically novel and challenging to the traditional forms of Judaism as the Maimonidean speculative presentation of Judaism. This mentalistic trend met, in Abulafia's case, an entirely different esoteric stream, represented at its peak by the various forms of the Ashkenazi traditions, but stemming from different centres in Italy, and plausibly part of an earlier Jewish tradition from the Middle East, which emphasised the linguistic elements of Jewish traditions, the canonicity of the Bible and liturgical texts, the centrality of divine names, and radical forms of exegesis that include, among other things, gematria and permutations of letters. ${ }^{96}$

Interestingly enough, while Maimonides's activity coincides with the Andalusian floruit of Muslim Neo-Aristotelianism, Maimonideanism developed in a period when Muslim Neo-Aristotelian philosophy had vanished as a significant living phenomenon in Islam. From the temporal point of view, it parallels the appropriation of NeoAristotelianism in some circles in Christian Europe. We may remark that like any transfer of a significant corpus of writings possessing a certain degree of coherence from one culture to another, this one provokes a change in the culture that acquires that corpus. This was also the case in Islam, Judaism, and, later, Christianity. However, it should be pointed out that in Jewish circles, due to the absence of a central authority, the impact of Neo-Aristotelianism was more widespread and longstanding, despite the sharp critique it initially encountered.

Let me distinguish, tentatively, between four major stages of Maimonideanism that are relevant for our discussion below. The first stage, that of Maimonides himself, is constituted by the application of Neo-Aristotelian categories to many topics in biblical and Rabbinic Judaism. Other figures who are a part of this stage include Joseph ibn 'Aqnin, Joseph al-Fawwāl, and Joseph ben Judah of Ceuta, all of whom were active in the Middle East and predominantly used Arabic as their philosophical language. The second phase consists of Maimonides's translators into Hebrew, such

96 This is an issue that deserves further investigation. See, meanwhile, the controversy between Israel Weinstock, “The Discovery of Abu Aharon of Baghdad's Legacy of Secrets” [Hebrew], Tarbiz 32 (1963): 153-59; Gershom Scholem, “Has Abu Aharon’s Legacy of Secrets Been Discovered?” [Hebrew], Tarbiz 32 (1963): 252-65; and the rejoinder by Israel Weinstock, “The Treasury of 'Secrets' of Abu Aharon-Imagination or Reality?” [Hebrew], Sinai 54 (1964): 226-59; Moshe Idel, "From Italy to Ashkenaz and Back: On the Circulation of Jewish Mystical Traditions," Kabbalah 14 (2006): 47-94; Moshe Idel, "Holding an Orb in His Hand: The Angel 'Anafi'el and a Late Antiquity Helios Mosaic," Ars Judaica 9 (2013): 19-44; Idel, Ben, 51, 55-56, 70, 194, 378; Idel, ““In a Whisper.” 
as Samuel ibn Tibbon and Judah al-Harizi, as well as his defenders, such as David Qimhi, during the first controversy over his books. These figures all wrote in Hebrew and were inhabitants of Western Europe. The third phase consists of additional translations of Arabic sources, some of which are important for understanding the Guide, either as its very sources or as simply helpful for explicating Maimonides's worldview. This stage is comprised of Jewish authors who were active after 1230, such as Jacob Anatoli, Moses ibn Tibbon, Rabbi Zerahyah ben Isaac ben She'altiel Hen (Gracian), and Qalonymus ben Qalonymus. They were inhabitants of the centres of Jewish culture, especially Provence, Catalonia, and southern Italy. The fourth phase, to which Abulafia may be described as belonging and which overlaps with the later part of the third phase, consists of the active dissemination of the Guide's views, either orally or in writing by means of commentaries on it and philosophical commentaries on Jewish scripture.

Although the thinkers in the first two stages had no positive association with Jewish mysticism, in the third and fourth stages, the situation changed, as some of the representatives of these moments in the developments of Maimonideanism sporadically refer to Kabbalistic writings or to earlier materials that informed Kabbalah, as is the case with Levi ben Abraham, Isaac Albalag, or Moses Narboni. Others, such as Rabbi Zerahyah Hen, sharply criticised these writings.

In the less than a hundred years since its completion in its original Arabic in distant Egypt, the reverberations of the Guide had transformed much of the intellectual landscape of Jewish Europe, as well as the Eastern provinces of Egypt, the Land of Israel, and other Jewish communities in Asia; all this despite the fierce critiques it encountered from a variety of major figures in Rabbinic Judaism. This transfer of Greek thought in disguise as Jewish esotericism generated a transformation of Judaism in several circles, and we shall be dealing in this study with some of its major developments.

Modern scholarship in the field advanced, roughly speaking, in accordance with this chronological scheme, which means that Maimonides's own writings and thought received and continue to receive maximum attention. It was only later, in the nineteenth century, that the books of Samuel ibn Tibbon and Jacob Anatoli were printed, while the two other later phases have received even less attention in both research into and publication of the writings as practised by scholars in the field in the last century and a half. However, in the last half-century, Jewish Western Maimonidean trends have been studied rather intensely by a long list of scholars ${ }^{97}$

97 The most important of them, in alphabetical order, are Alexander Altmann, Kalman Bland, Isaac E. Barzilay, Gerrit Bos, Igor De Souza, Zvi Diesendruck, Esti Eisenmann, Seymour Feldman, Resianne Fontaine, Carlos Fraenkel, Gad Freudenthal, Jacob Friedman, Ottofried Fraisse, Ruth Glasner, Naomi Grunhaus, Moshe Halbertal, Racheli Haliva, Avraham Halkin, Steven Harvey, Warren Zev Harvey, Maurice Hayoun, Sara O. Heller-Willensky, Gitit Holzman, Alfred L. Ivry, Raphael Jospe, Hannah Kasher, Menachem Kellner, Howard (Haim) Kreisel, Jacob Levinger, Charles H. Manekin, Barry Mesch, Abraham Nuriel, Shlomo Pines, Aviezer Ravitzky, Caterina Rigo, James Robinson, Shalom 
whose studies deal with some aspects of the writings of Moses ibn Tibbon, Isaac ben Abraham ibn Latif, Jacob ben Makhir (Don Profatius), Moses of Salerno, Nathan ibn Tibbon, Hillel of Verona, Rabbi Zerahyah ben She'altiel Hen, Shem Tov ibn Falaquera, Isaac ben Yeda'yah, Yeda'yah ha-Penini of Beziers, Levi ben Abraham ben Hayyim of Villefranche, Isaac Albalag, Isaac Polqar, Nissim ben Moses of Marseilles, Menahem ha-Me'iri, Samuel ben Judah of Marseilles, Joseph ibn Kaspi, Qalonymus ben Qalonymus (Maestro Kalo), Immanuel of Rome, Judah ben Moses Romano, Gersonides, and Moses Narboni, to name only the most important early Maimonideans. In addition to their own writings related to Maimonides himself, such as their commentaries on the Guide, and a concentration on biblical exegesis, as some Maimonideans produced, some of them also translated a variety of philosophical books from Arabic, making this group's production even more impressive from a quantitative point of view.

Though active in Christian hegemonic territories for several centuries, the wide spectrum of Western Maimonideanism echoed much of the results of the intellectual developments that took place in Islamicate provinces during the preceding three centuries of appropriating and elaborating some forms of Greek and Hellenistic philosophies. These appropriations of ancient Greek thought that occurred in medieval Muslim and Jewish cultures and the floruit of the latter Neo-Aristotelianism in Christian provinces are fine examples of the poverty of historicism, which attempts to reduce complex phenomena to events that took place in their immediate environment. Moreover, the differences between Platonism and Aristotelianism, and the eventual syntheses between them, reverberated not only in late antique Hellenism in Alexandria and Rome, but also in Muslim and Jewish philosophies and Kabbalah in the Middle Ages. They also had an impact on Jewish thought during the eighteenth-century Enlightenment, as we shall see below in Appendix B.

The Jewish thinkers mentioned above, different as they are from each other, may nevertheless be considered as part of a broader philosophical movement. It is only in Colette Sirat's recent history of medieval philosophy that they have been paid greater attention. Thanks to her earlier extensive study of their manuscripts, in this survey, she integrates their thought into a more comprehensive history of Jewish philosophy, including the views of Abraham Abulafia, for the first time. ${ }^{98}$ In this context, it is im-

Rosenberg, Shalom Sadik, Marc Saperstein, Dov Schwartz, Yossef Schwartz, Joseph B. Sermoneta, Joseph Schatzmiller, Yair Shiffman, Colette Sirat, Gregg Stern, Frank Talmage, Charles Touati, Isadore Twersky, Georges Vajda, and Mauro Zonta. In the present framework, it is difficult to refer to all the studies by those scholars, but their findings allow a much better picture than what we had a generation ago. The more comprehensive picture that the Maimonideans formed has served as the background of my studies on Abulafia since the beginning.

98 See her La philosophie juive médiévale en pays de chrétienté (Paris: Presses de CNRS, 1988). Compare to the pioneering, though somewhat biased, monograph by Isaac Barzilay, Between Reason and Faith: Anti-Rationalism in Italian Jewish Thought 1250-1650 (The Hague/Paris: Mouton 1967), whose first part deals with Rabbi Hillel and Zerahyah, though Abulafia appears only on the margin of his analyses. 
portant to point out the five voluminous tomes of writing by Maimonideans that were recently printed with introductions, footnotes, and indexes (some of them facilitated by Sirat's previous research) by Howard Kreisel. Kreisel has thus made important material available for understanding the allegorical trends thriving in the generation following Abulafia's floruit. ${ }^{99}$ This goal is also evident in the case of James T. Robinson's publication of Samuel ibn Tibbon's Commentary on Ecclesiastes, ${ }^{100}$ Yair Shiffman's critical edition of Rabbi Shem Tov ibn Falaquera's Moreh ha-Moreh, ${ }^{101}$ and Hannah Kasher's critical publication of ibn Kaspi's Šulhan Kesef with introduction and footnotes, ${ }^{102}$ as well as the recent printing of some of the Hebrew translations of Arabic texts made by the Maimonideans. ${ }^{103}$

However, what can be seen from those voluminous writings is a form of epigonism, which means that all these writers were writing under the wings of the Great Eagle, ${ }^{104}$ though the complexity generated by his greatness in both legalistic and philosophical studies is immesurably greater in comparison to his followers. Nothing resembling the Guide has been produced that amplifies its project; rather, attempts were made to clarify and apply the insights Maimonides presented or hinted at in his chef d'oeuvre. In other words, quantity is indeed obvious in the case of the Maimonideans, but much less so intellectual originality. If the main problem of the Guide was how to hint at secrets without revealing them, Maimonides's followers revealed what they believed those secrets were without too many hints, which means that esotericism weakened dramatically, given the proliferation of writings on the same topics addressed by the Guide. I would say that very few new secrets were invented in what can be called the Maimonideans' super-commentaries. As mentioned in the previous chapter, the Maimonideans were much more exoteric writers than their model, though Abulafia is somewhat closer to Maimonides due to his emphasis on the need for esotericism, as we shall see below.

99 Levi ben Abraham, Liwyat Hen, Ma'aśeh Berešit (Jerusalem: The World Union of Jewish Studies, 2004); Levi ben Abraham, Liwyat Hen: The Quality of Prophecy and the Secrets of the Torah; Levi ben Avraham, Liwyat Hen: The Work of the Chariot, ed. Howard Kreisel (Jerusalem: World Union of Jewish Studies, 2013); Nissim ben Moses of Marseilles, Ma'aśeh Nissim, ed. Howard Kreisel (Jerusalem: Mekize Nirdamim, 2000); and Moses ibn Tibbon, The Writings of Rabbi Moses ibn Tibbon: Sefer Pe'ah, Ma'amar Ha-Taninim, Peruš ha-Azharot Le-Rav Solomon ibn Gabirol, eds. Howard Kreisel, Colette Sirat, and Avraham Israel (Be'er-Sheva: Ben-Gurion University Press, 2010). See also his “A Fragment from a Commentary on Ruth Ascribed to Rabbi Nissim of Marseilles” [Hebrew], JSJT 14 (1998): 159-80. 100 Samuel ibn Tibbon, Samuel ibn Tibbon's Commentary on Ecclesiastes: The Book of the Soul of Man, ed. James T. Robinson (Tübingen: Mohr Siebeck, 2007). See also Liron Hoch, "The Philosophy of Samuel ibn Tibbon and Rabbi David Kimhi as Background for Abrabanel's Philosophical Approach" [Hebrew], Da'at 77 (2014): 123-41.

101 Rabbi Shem Tov ibn Falaquera, Moreh ha-Moreh.

102 Joseph ibn Kaspi, Šulhan Kesef, ed. Hannah Kasher (Jerusalem: Ben Zvi Institute, 1996).

103 See below chapter 4, notes 60, 61 .

104 See Robinson, “We Drink Only from the Master’s Water," 27-60. 
The members of this conceptual movement were sometimes aware of each other and quoted their predecessors, especially the members of the ibn Tibbon family. However, what seems to me to be more interesting for our approach towards Abulafia's allegoresis is the similarity between the members of the Maimonidean camp as a whole. Even when they comment on the same issue independently, they offer similar solutions because of their shared hermeneutical grid profoundly informed by both Neo-Aristotelianism and Abulafia's allegoresis.

Some of those thinkers began their education or even their activity in Al-Andalus, although they had to leave this region for Southern France, especially Provence. In their first generation, they were part of the Muslim philosophical culture; later on, they were part of what I call the Jewish Andalusian internationale. ${ }^{105}$ This means that the Andalusian refugees from the Almohad persecutions that had occurred since 1145, who arrived in Provence in the second half of the twelfth century and who mastered both Arabic and the philosophical sources written by the falāsifah, translated and defended Maimonides's books written in remote Egypt. They even translated some writings by Muslim philosophers, mainly of Andalusian extraction, into Hebrew. Both types of translations constituted the first layer of the conceptual development that can be called Maimonideanism. Later, this development turned into a movement that constituted the Western Jewish Maimonidean tradition. The impact of the Jewish translators' work on Christian scholasticism and that of Christian scholasticism on some Maimonideans should also be taken into consideration.

The Eastern Maimonidean tradition, which has been studied separately, is mainly represented by Maimonides's descendants and Yemenite Jews and is less relevant to the points we would like to make here. It should be mentioned that even Muslim thinkers in the East studied the Guide ${ }^{106}$ Moreover, several Karaite thinkers were also influenced by Maimonides. ${ }^{107}$ Though the two forms of Maimonideanism differ so dramatically, the Western more Averroistic and the Eastern more Sufi-oriented,

105 See Idel, "Maimonides's Guide of the Perplexed and the Kabbalah," 197-99, and compare to Narboni, Commentary on the Guide, fol. 15b.

106 See Paul Fenton, “The Literary Legacy of Maimonides' Descendants," in Sobre la Vida y Obra de Maimónides, ed. Jesús Peláez del Rosal (Córdoba: Ediciones El Almendro, 1991): 149-56; Fenton, "A Judaeo-Arabic Commentary on Maimonides’s Mišne Tora by Rabbi David Ben Joshua Maimonides (ca. 1335-1414)" [Hebrew], in Heritage and Innovation in Medieval Judaeo-Arabic Culture: Proceedings of the Sixth Conference of the Society for Judaeo-Arabic Studies, eds. Joshua Blau and David Doron (Ramat-Gan: University of Bar-Ilan Press, 2000): 145-60; and David R. Blumenthal, "Was There an Eastern Tradition of Maimonidean Scholarship?” REJ 138 (1979): 57-68. On esotericism among Maimonides's descendants in the East, see David R. Blumenthal, "An Epistle on Esoteric Matters by David II Maimonides from the Geniza," in Pesher Nahum; Texts and Studies in Jewish History and Literature from Antiquity Through the Middle Ages Presented to Norman (Nahum) Golb, eds. Joel L. Kraemer and Michael G. Wechsler (Chicago: The Oriental Institute of the University of Chicago, 2012): 57-74, where permutations of letters of the divine name are mentioned on page 67.

107 See Daniel J. Lasker, “Maimonides' Influence on Karaite Theories of Prophecy and Law," Maimonidean Studies 1 (1990): 99-115. 
they were in contact with each other, though a significant reciprocal influence between the two is rather difficult to discern.

The differences between the various Maimonideans in the West notwithstanding, they share some interesting common denominators that are incongruent with Maimonides's Guide of the Perplexed: one of which is the assumption that it is possible to conjoin with the Agent Intellect. In some cases in the Western branch, this assumption was coupled with the possibility that because of this conjunction, a person is capable of momentarily changing the course of events in nature. These two issues will be discussed below, for example, in chapter $7 .{ }^{108}$ Another common denominator is the expansion of the range of sources that were included in the writings of the Maimonideans, who were more inclusive than the Great Eagle. This fact contributed to a certain conceptual diversification-and we should see Abulafia in this view-as one major and independent variant among others.

Insofar as I am concerned with this phenomenon here, the Jewish Western Maimonideans were mainly active during the century and a half after Maimonides's death. Their activity is contemporaneous with the emergence of Kabbalah and its most decisive phases of expansion. In addition, there is also some geographical overlap between the two expanding literatures: they flourished in Provence, Spain, and Italy. Though far from constituting a unified tradition, the Maimonidean thinkers shared a strong interest in Maimonides's books on the one hand and in the philosophical sources in the Muslim world that constituted his conceptual background (Al-Fārābī, Avicenna, and the Andalusian falāsifah: ibn Bāğğah, ibn Ṭufayl, and Averroes) on the other. Those sources were eventually combined with additional types of sources, especially Neo-Platonic ones, the writings of Abraham ibn Ezra, and, though more rarely, even with Kabbalistic themes, sometimes part of the encyclopaedic tendency of these generations, as Rabbi Judah ibn Matkah's Midrash Hokhmah, Rabbi Shem Tov Falaquera's De'ot ha-Filosofim, ${ }^{109}$ and Rabbi Levi ben Abraham's Liwyat Hen and Battei ha-Nefeš we-ha-Lehašim ${ }^{110}$ show. The latter two authors were Abulafia's contemporaries, and he had read the former's book, as we shall discuss in chapter 6.

108 See also below chapter 3, note 108, Levi ben Abraham, Liwyat Hen, Ma'aśeh Berešit, 135-36, 367-68; Levi ben Avraham, Liwyat Hen: The Work of the Chariot, 133; Nissim ben Moses of Marseilles, Ma'aśeh Nissim, 438; Joseph (Ynon) Fenton, "The Theory of Devequt in the Doctrine of Rabbi Abraham the Son of Maimonides" [Hebrew], Da'at 50-52 (2003): 107-19; Moshe Narboni, as discussed in Idel, Studies in Ecstatic Kabbalah (1988), 63-67; and Gitit Holzman, "Seclusion, Knowledge and Conjunction in the Thought of Rabbi Moshe Narboni” [Hebrew], Kabbalah 7 (2002): 111-73, especially 143-50 and 164-68. See also the interesting passage by the thirteenth-century Provençal author Rabbi Isaac ben Yeda'ayah, as quoted in Idel, Studies in Ecstatic Kabbalah, 21, note 11.

109 Steven Harvey, “Shem Tov Falaquera's De'ot ha-Filosofim: Its Sources and Use of Sources," in The Medieval Hebrew Encyclopedia of Science and Philosophy, ed. Steven Harvey (Dordrecht: Kluwer Academic Publishers, 2000): 211-47.

110 See Warren Zev Harvey, “Levi Ben Abraham of Villefranche's Controversial Encyclopedia,” in The Medieval Hebrew Encyclopedia of Science and Philosophy, 171-88. 
Abulafia's specific generation is a special one, especially when we look at it from the point of view of European culture. The Maimonideans indeed accelerated their literary activity in his lifetime, but they did not produce a major new form of philosophical thought. However, at the same time, Thomas Aquinas wrote his Summa, the Kabbalists produced the vast Zoharic literature, and, somewhat later, Dante Alighieri produced his Divina Commedia, ${ }^{111}$ undoubtedly all major cultural achievements. Western Maimonideanism, however, turned into a less creative, somewhat scholastic type of writing. It is against this relatively inertial or epigonic background that Abulafia's intellectual creativity will be better understood.

From the point of view of creativity rather than its content, Abulafia's vast literary legacy is temporally paralleled by the outburst of production by the theosophical-theurgical Kabbalists flowering in Castile, especially the vast Zoharic literature, though both the experiential and the conceptual structures are substantially different and in many cases opposite in their visions of religion, as we shall see in more detail later in this chapter and in chapter 27. What they have in common, however, is the substantial influence of Ashkenazi thought that became more prominent in Spain in the second part of the thirteenth century, though they integrated its thought and practices in different ways. While Abulafia was mainly interested in the Ashkenazi mystical techniques and exegetical linguistic methods, the Castilian Kabbalists were more interested in Ashkenazi customs and magical devices, the so-called "name for delivering sermons" or "name for speedy writing" that may be a reference to speed-copying.

It should be pointed out that there was a sharp division of labour evident in the writings of two main figures of scholarship in Jewish thought: Julius Guttmann, a leading scholar of Jewish philosophy, and Gershom G. Scholem, the eminent scholar of Jewish mysticism. In the former's many studies dedicated to the Maimonideans, there are very few references to the numerous pieces of information and modes of interpreting the Guide found in the writings of Rabbi Abraham Abulafia. ${ }^{112}$ This ne-

111 See Sandra Debenedetti Stow, Dante e la mistica ebraica (Florence: Giuntina, 2004). On the questions related to Averroism, Thomas, and Dante, including the questions of intellect and imagination, see Giuseppe Mazzotta, Dante's Vision and the Circle of Knowledge (Princeton: Princeton University Press, 1993), 116-34.

112 The only significant exceptions are Ravitzky's relatively short remarks in "Secrets of the Guide," 172-73; Warren Zev Harvey's remark in his “A Third Approach to Maimonides' Cosmogony-Prophetology Puzzle,” 293; Yossef Schwartz, "Magic, Philosophy and Kabbalah: The Mystical and Magical Interpretation of Maimonides in the Later Middle Ages," in Maimonides and Mysticism, 99-132; and Hannah Kasher, “Where Did Maimonides Explain the Homonymity of the Name Ben?” [Hebrew], Tarbiz 63 (1994): 239. However, even in Schwartz's remarks, it is not the philosophical aspects of Abulafia's writings that are addressed, but only discussions of the divine names in his writings. The only major scholar who attempted to deal with a specific text by Abulafia in one of the commentaries on the secrets of the Guide was Alexander Altmann in his "Maimonides' Attitude toward Jewish Mysticism," but he also essentially regarded Abulafia as representative of the Kabbalists rather than as a part of the philosophical camp. See, for example, the resort to Sefer Ner Elohim (a treatise from Abu- 
glect is questionable because for some formative years in his life, he was, as we shall see below, part and parcel of this tradition and continued to adhere to it even after he became a Kabbalist.

This rich philosophical tradition written in Hebrew in Abulafia's generation, conceived as a potential reservoir for comparison with his writings, has also not been addressed in a detailed manner in most of the studies of Abulafia written by scholars of Kabbalah, which follow Scholem's too-stark distinction between Kabbalah and Jewish philosophy. I have attempted to do so in the case of Abulafia's original approach in Kabbalah towards two of his most important issues: mystical union and the understanding of his intellectual messianism.

The weight of the phenomenological similarities between Abulafia's and Maimonides's thought, as well as the similarities between the Maimonideans and their Muslim philosophical sources, is considerable and should be taken much more into account, especially given that it touches two of the most sensitive aspects of Abulafia's Kabbalistic thought: the nature of prophecy and the noetic character of mystical union. ${ }^{113}$ This similarity is also quite obvious in the central role played by the Agent Intellect as understood by Maimonides and the faläsifah: it functions as the ruler of this world, both in the writings of the Maimonideans and in those of Abulafia, deeply transforming their understanding of religion not just into an intellectual enterprise, but also into an orientation towards an entity that is not identical with the highest power within the universe. ${ }^{114}$ If the role of this intellectual apparatus that concerns both the cosmic and the human levels is paramount, the question should be how other views and approaches that do not fit the Neo-Aristotelian approach may be understood in such a framework.

In attributing such a paramount role to this seminal concept in both types of Maimonideanism (the philosophical and the ecstatic Kabbalistic), some aspects of earlier forms of Judaism underwent a sharp intellectualistic restructuring, and this is also alien to the gist of the other Kabbalistic schools in the thirteenth century, the theosophical-theurgical Kabbalah, and the contemporary Ashkenazi literature. In the rare cases when Kabbalists in this period mentioned it, this concept played only a marginal role, although it was connected in this case to a much higher level than in the Arabic Jewish philosophical tradition. ${ }^{115}$ It should be noted that

lafia's school, though it is not his own book) in Howard Kreisel's attempt to reconstruct the theosophical material found in Rabbi Levi ben Abraham's writings in his introduction to Liwyat Hen: The Work of the Chariot, 95-96. Here, I am more concerned with the consonance between Abulafia's philosophical views and those of Maimonides and the Maimonideans.

113 See also Afterman, “And They Shall Be One Flesh,” 152-70.

114 See Davidson, Alfarabi, Avicenna, and Averroes on Intellect. For a sharp designation of the Agent Intellect as the ruler of the world, see Abulafia's Or ha-Śekhel, ed. Gross (Jerusalem: 2001), 29: אדון כל העולמים. In the same context, the Agent Intellect is designated as “all.” See also Oșar Eden Ganuz, 1:3, 139, where it is also called the "King of the World": מלך העולם "

115 See the important footnote in Assi Farber, "On the Sources of Rabbi Moses de Leon's Early Kabbalistic System” [Hebrew], in Studies in Jewish Mysticism, 85-86, note 43. 
the ecstatic Kabbalist often related the philosophical term "ruler of the sublunary world" to the functions of the angel Metatron, who played a central role in earlier Jewish esoteric literature because of his traditional role as a scribe writing the merits of Israel; that is, he was someone who was involved in a type of linguistic activity.

In fact, Abulafia's writings aside, it is surprising to see how great the polarisation was between the theosophical Kabbalists on the one hand and the Maimonidean authors on the other, even in the cases of the few Kabbalists who were acquainted with philosophy earlier in their careers as Rabbi Moses de Leon ${ }^{116}$ and Rabbi Joseph Gikatilla were. ${ }^{117}$ A perusal of Kabbalistic writings in the last third of the thirteenth century and the beginning of the fourteenth century will easily show how Kabbalistic theosophical nomenclature is essentially independent of the philosophical languages practised (mainly by the Maimonideans) in their immediate vicinities (which is also true vice versa). Even when phrases or themes had been adopted from philosophical texts, they were absorbed and adapted within broader theosophical structures whose basic approach differs from the philosophical ones, to a great extent changing the original meaning of what the Kabbalists were borrowing; examples of this adoption and strong adaptation are legion.

Indeed, let me point out an important issue: the Maimonideans adopted Maimonides's profound conceptual structure, not just his philosophical terminology. This adoption is evident even in cases where they adapted forms of thought from other speculative sources. On the other hand, they were much less concerned with Maimonides's legalistic writings and their implications for understanding Maimonides the theologian or philosopher. To a great extent, this is also the case with Abraham Abulafia, who also resorted to linguistic mysticism and to some form of astral magic, despite the substantial modifications he introduced into the Maimonidean mode of thought as described above. In my opinion, he grafted linguistic methods and speculations onto a philosophical religion as he understood it, mainly in the Maimonidean version, thereby creating an ecstatic religion that consisted in the search for experiences he called prophecy, while others envisioned these experiences as a union with the intellectual world.

Both types of experiences are repeatedly mentioned in Abulafia's writings, and this is the reason why I understand his ideals as more comprehensive than the pursuit of experiences of revelations that can be described as prophecy alone. Hence my

116 See Scholem, Major Trends in Jewish Mysticism, 203, 397-98, note 154; Rabbi Moses de Leon, The Book of the Pomegranate, ed. Elliot R. Wolfson (Atlanta: Scholars Press, 1988), 36-38, 390-92; Elliot R. Wolfson, A Dream Interpreted Within a Dream: Oneiropoiesis and the Prism of Imagination (New York: Zone Books, 2011), 256, note 161; and Avishai bar-Asher, "Penance and Fasting in the Writings of Rabbi Moses de Leon and the Zoharic Polemic with Contemporary Christian Monasticism,” Kabbalah 25 (2011): 300-303.

117 See Joseph ben Abraham Gikatilla, Ginnat Egoz (Jerusalem: Yeshivat Ahavah we-Hayyim, 1989), 168, 340-41, 345-47, as well as his critique of Maimonides in his Haśśagot. See chapter 5 note 210 below. 
resort to the term "ecstatic Kabbalah" covers unitive and/or prophetic valences, as well as precise techniques. Let me emphasise something that in my opinion is self-evident: Abulafia cultivated ecstatic experiences of more than one type. At the same time, he created an extensive literature devoted to describing his original techniques for reaching ecstatic experiences as he imagined them. In principle, an ecstatic mystic does not have to create a literature that is ecstatic in its main target: he may not create any literature at all.

However, in the case of the main schools of Kabbalah in Provence, Catalonia, and Castile, Kabbalists had their own systems; namely, theosophies, which, different as they are from each other, are nevertheless sharply different from and incompatible with Maimonides's metaphysics. This does not mean that Kabbalists were not acquainted with Maimonides's books, or, at least, with his ideas. As I understand it, what they decided to adapt from his writings was a few disparate themes that did not affect their major concerns which were founded in the theosophical-theurgical model. In short, unlike Abulafia's profound conceptual structure, which is fundamentally Neo-Aristotelian, nothing as significant as a profound structure shaped by Neo-Aristotelianism can be discerned in earlier and contemporary theosophicaltheurgical Kabbalah. Without being aware of the structural and conceptual differences between the different literatures, the different literary genres, and the specific nomenclatures that were dominant in their writings, scholars may only deal with marginal themes and exaggerate the significance of their findings, reflecting a dimension that is actually much less significant than they are inclined to believe.

Nevertheless, the development of Jewish thought in the thirteenth century should be seen in a more integrated manner than it has been previously. It should be seen as a domain constituted of diverging trends that are simultaneously competing, criticising, and enriching each other. If the Jewish philosophers, following earlier sources, introduced the importance of constant order, the idea of the organised cosmos, to be found in both God and reality, the main line of Kabbalah elaborated on the importance of the divine dynamic nature, which is dependent on human activity, a phenomenon that I propose to call theurgy. ${ }^{118}$ This phenomenon that sees the dy-

\footnotetext{
118 See Idel, Kabbalah: New Perspectives, 173-99; Moshe Idel, "From Structure to Performance: On the Divine Body and Human Action in the Kabbalah" [Hebrew], Mišqafayyim 32 (1998): 3-6; Idel, Absorbing Perfections, 3, 13, 31, 60, 67, 73-74; Idel, Ascensions on High, 7, 11, 16-18, 68, 114-15, 120-21; Moshe Idel, "On the Performing Body in Theosophical-Theurgical Kabbalah: Some Preliminary Remarks," in The Jewish Body: Corporeality, Society, and Identity in the Renaissance and Early Modern Period, eds. Maria Diemling and Giuseppe Veltri (Leiden/Boston: Brill, 2009): 251-71; Moshe Idel, "Some Remarks on Ritual and Mysticism in Geronese Kabbalah," JJTP 3 (1993): 111-30; Idel, Enchanted Chains, 33-34, 47, 215-20; Idel, "On the Identity of the Authors of Two Ashkenazi Commentaries to the Poem ha-Aderet we-ha-Emunah”; Charles Mopsik, Les grands textes de la Cabale: les rites qui font Dieu (Paris: Verdier, 1993); Yair Lorberbaum, Image of God, Halakhah and Aggada [Hebrew] (Tel Aviv: Schocken, 2004); Jonathan Garb, Manifestations of Power in Jewish Mysticism: From Rabbinic Literature to Safedian Kabbalah (Jerusalem: Magnes Press, 2005); Elliot R. Wolfson, "Mystical-Theurgical Dimensions of Prayer in Sefer ha-Rimmon," Approaches to Judaism in Medieval Times 3 (1988): 41-
} 
namic order as dependent on human actions was central for the development of Kabbalah from its historical inception in the last third of the twelfth century. Understanding Abulafia should therefore take the path of a person at the crossroads of a variety of intellectual trends choosing paths that he deems to be cogent to his thought. The nature of his choice can be discerned by examining some of this Kabbalist's texts which have not received due attention in scholarship.

Let me point out one of the major frameworks of the present book. In recent years, the focus of scholarship concerning Abulafia's sources has moved in two new directions. The most visible tendency has been the emphasis on his interactions with Christianity and its impact on his thought. This tendency can be found in the studies by Hames, Wolfson, Sagerman, and, more recently and to a lesser degree Pedaya, all of whom claim the existence of new facets of this impact, ${ }^{119}$ going far beyond what I already proposed on this topic in my earlier work. ${ }^{120}$ The second new direction has been the suggestion regarding the greater influence of Sufism on the ecstatic Kabbalist, as Hames and Pedaya claimed to have discerned. ${ }^{121}$ In this study, only some aspects of the first of the two recent trends will be discussed.

It should be stressed from the very beginning that the existence of such influences, even if they were proven, does not affect the possibility of Abulafia having a centre of gravity that is conceptually different from those specific sources. The existence of divergent types of sources does not, in my opinion, constitute a problem, and these suggestions, even if they were proven-of which I am far from being convinced-do not have to be understood as exclusive in regard to the much more decisive impact of Maimonidean thought on Abulafia, coupled as it also is with other Andalusian philosophical sources.

However, the problem with those other proposals is that they have been articulated without the support of explicit references that could be found in Abulafia's writings on specific books or authors, without the discovery of the existence of specific terminology shared in a historical background, before a serious inspection of the alternative sources that Abulafia himself mentions in his books, and, finally, without making any attempt to explore the range and depth of the impact of those

79. For the theurgical aspects of Rabbi Joseph Ashkenazi's thought, see his Commentary on Genesis Rabbah, 40, 274, and Mopsik, Chemins de la cabale, 150, 218, 220, 356, 509 (who believes this Kabbalist to be a Spanish author!).

119 See Hames, Like Angels on Jacob's Ladder; Wolfson, Abraham Abulafia; Sagerman, The Serpent Kills; and Haviva Pedaya, "The Sixth Millennium: Millenarism and Messianism in the Zohar" [Hebrew], Da'at 72 (2012): 85-87.

120 See, for example, Messianic Mystics, 295-301.

121 See Haviva Pedaya, Vision and Speech: Models of Revelatory Experience in Jewish Mysticism [Hebrew] (Los Angeles: Cherub Press, 2002), 195-98 and Harvey J. Hames, "A Seal within a Seal: The Imprint of Sufism in Abraham Abulafia's Teachings," Medieval Encounters 11 (2006): 153-72. For my assessment as to the importance of the Muslim influence on Kabbalah, see "Orienting, Orientalizing or Disorienting the Study of Kabbalah: 'An Almost Absolutely Unique' Case of Occidentalism," Kabbalah 2 (1997): 13-48, with references to my previous discussions on this topic. 
sources which Abulafia actually repeatedly says nourished his thought. This is the reason why even a tentative acquaintance with merely the titles of those sourcesand even more with their contents-is absolutely necessary before making more solid claims as to possible contributions of additional sources to Abulafia's thought that were not explicitly mentioned by the ecstatic Kabbalist.

Nevertheless, let me emphasise that it is important that attempts have been made to point towards alternative understandings of Abulafia's thought and thus to open the possibility of addressing his views in a broader perspective. However, laudable as such efforts are in principle (indeed, references to non-Jewish sources may open the possibility of a better understanding of the influences on Jewish thought that existed at that time), they should be judged not by their originality, but by their explanatory power. ${ }^{122}$ Without being aware of what Abulafia's selective affinities and more comprehensive worldview were, it is difficult to see what is merely a marginal borrowing in his thought and what material constitutes the profound structures that informed it. That his thought is essentially noetic points to Abulafia's being part of the history of Maimonideanism. Moreover, his political esotericism dramatically differentiates him from the vast majority of Kabbalists.

122 See my Studies in Ecstatic Kabbalah, 33. 